IZA DP No. 4897

Disability in the Welfare State:

An Unemployment Problem in Disguise?

Bernt Bratsberg

Elisabeth Fevang

Knut Røed

April 2010 


\title{
Disability in the Welfare State: An Unemployment Problem in Disguise?
}

\author{
Bernt Bratsberg \\ Ragnar Frisch Centre for Economic Research \\ Elisabeth Fevang \\ Ragnar Frisch Centre for Economic Research \\ Knut Røed \\ Ragnar Frisch Centre for Economic Research \\ and IZA
}
Discussion Paper No. 4897
April 2010

IZA

P.O. Box 7240

53072 Bonn

Germany

Phone: +49-228-3894-0

Fax: +49-228-3894-180

E-mail: iza@iza.org

\begin{abstract}
Any opinions expressed here are those of the author(s) and not those of IZA. Research published in this series may include views on policy, but the institute itself takes no institutional policy positions.

The Institute for the Study of Labor (IZA) in Bonn is a local and virtual international research center and a place of communication between science, politics and business. IZA is an independent nonprofit organization supported by Deutsche Post Foundation. The center is associated with the University of Bonn and offers a stimulating research environment through its international network, workshops and conferences, data service, project support, research visits and doctoral program. IZA engages in (i) original and internationally competitive research in all fields of labor economics, (ii) development of policy concepts, and (iii) dissemination of research results and concepts to the interested public.
\end{abstract}

IZA Discussion Papers often represent preliminary work and are circulated to encourage discussion. Citation of such a paper should account for its provisional character. A revised version may be available directly from the author. 
IZA Discussion Paper No. 4897

April 2010

\section{ABSTRACT}

\section{Disability in the Welfare State: An Unemployment Problem in Disguise?*}

Economies with low unemployment often have high disability rates. In Norway, the permanent disability insurance rolls outnumber registered unemployment by four to one. Based on administrative register data matched with firms' financial statements and closure data collected from bankruptcy proceedings, we show that a large fraction of Norwegian disability insurance claims can be directly attributed to job displacement and other adverse shocks to employment opportunities. For men, we estimate that job loss more than doubles the risk of entry to permanent disability and that displacements account for fully 28 percent of all new disability insurance claims. We conclude that unemployment and disability insurance are close substitutes.

JEL Classification: H55, I12, I38, J63, J65

Keywords: disability, displacement, social insurance, employment opportunities

Corresponding author:

Knut Røed

The Ragnar Frisch Centre for Economic Research

Gaustadalléen 21

0349 Oslo

Norway

E-mail: knut.roed@frisch.uio.no

\footnotetext{
* We are grateful to Oddbjørn Raaum, Mari Rege, Kjell Gunnar Salvanes, and Kjetil Telle for valuable comments. We acknowledge funding from the Norwegian Research Council (grant \#173583/internal project \#1156). The paper is part of the research activities of the centre of Equality, Social Organization, and Performance (ESOP), University of Oslo. Data made available by Statistics Norway have been essential for the research project.
} 


\section{Introduction}

Economies with low unemployment rates often have high disability rates. The pattern is particularly striking in the North-European welfare states. According to recent OECD statistics, the 2007 disability rates of Denmark, Finland, Norway, Sweden, and the Netherlands ranked among the top six out of the 28 industrialized nations for which comparable statistics are available (OECD, 2009, p. 14). These five countries are also well known for their low unemployment rates; e.g., in 2007 their average unemployment rate was 4.5 percent compared to 7.1 for OECD Europe as a whole (OECD, 2008, p. 335). Existing empirical evidence points to a certain degree of substitution between unemployment- and disability insurance program utilization; see Black et al. (2002), Autor and Duggan (2003), and Rege et al. (2009). A natural question to ask is whether low unemployment and high disability rates are two sides of the same coin, and whether disability pension sometimes is unemployment insurance in disguise.

The question is especially pertinent to recent developments in Norway. Between 1993 and 2006, Norway experienced a staggering rise in the fraction of the working-aged population who received health-related social security benefits - from 15.2 to 20.4 percent (Bratsberg et al., 2010a). Over the same period, the ratio of permanently disabled to the number of unemployed rose from 1.2 to 4.0 . This growth in disability rolls occurred without any parallel deterioration in health conditions. To the contrary, general health appears to have improved: The proportion of the adult population reporting good or very good health rose from 79 percent in 1995 to 81 percent in 2005, and the share reporting 
bad or very bad health declined from 8 to 6 percent. ${ }^{1}$ A plausible interpretation of the divergent trends in health and disability is that disability claims do not arise from health impairments alone, but that they arise from health impairment in combination with poor employment opportunities, or even from poor employment opportunities alone. In that case, new entries into disability may not typically be triggered by health shocks, but rather by deteriorating individual employment opportunities. This is what we refer to as "unemployment in disguise." We emphasize that we use this term to denote cases where unemployment causes disability; we do not imply that such disability claims are necessarily illegitimate in the sense that they do not entail health problems. Particular health problems may be disqualifying with respect to certain jobs, but not with respect to others. And, as pointed out by Bound and Burkhauser (1999), the loss of job-specific human capital associated with displacement might undermine future (attractive) job opportunities. Displacement may also reinforce pre-existing health conditions and even generate new ones; see, e.g., Eliason and Storrie (2009a) and Sullivan and von Wachter (2009). Our study is motivated by the idea that the distinction between unemployment and disability is blurred, and, hence, that there is scope for classifying similar work limitations differently in different social insurance environments. In fact, there are strong indications in prior studies from Norway that unemployment might be among the key drivers of labor market detachment processes leading to permanent disability; see Bratberg (1999), Dahl et al. (2000), Rege et al. (2009), and Bratsberg et al. (2010b). In order to devise appropriate strategies for curbing the rise in disability, it is important to establish empirically the

\footnotetext{
${ }^{1}$ These numbers are collected from Statistics Norway's level of living sample surveys, and can be downloaded from www.norgeshelsa.no.
} 
extent to which lack of employment opportunities actually is the triggering event behind entries into disability programs.

The present paper provides new insights on the causal relationship between individual employment opportunities and the risk of becoming a disability benefit claimant. Since the risks of disability and unemployment are likely to be highly correlated at the individual level, we face difficult identification problems. Our empirical strategy is to exploit exogenous sources of variation in individual employment opportunities, generated by variation in employers’ economic performance (including profitability, downsizing, and firm closure) and idiosyncratic fluctuations in local industry-specific labor market tightness, to identify the causal impacts. The empirical basis is administrative employeremployee registers, augmented with the firms' audited accounts and information collected from bankruptcy courts. The bankruptcy data make it possible to distinguish genuine mass layoffs from organizational restructuring, demergers, and takeovers.

Our empirical analysis relates closely to two recent studies using Norwegian employer-employee data, Rege et al. (2009) and Huttunen et al. (2010), and more loosely to a broader international literature addressing the consequences of job displacement; see, e.g., Hamermesh (1987), Ruhm (1991), Neal (1995), Kletzer (1998), Kuhn (2002), and Hallock (2009). The present paper extends the existing literature in several directions. It is, to our knowledge, the first study to exploit data on mass layoffs resulting from recorded bankruptcies in order to identify the impacts of exogenous displacement on the subsequent disability and non-participation propensities of affected workers. It is also the first study to examine the impacts of continuing firms' economic performance (i.e., the rate of return on their capital). In addition, we have constructed measures of local indus- 
try-specific labor market tightness to examine the impacts of shifts in local labor demand. These measures are designed to represent idiosyncratic fluctuations in labor market tightness across regions and industries, such that they by construction do not pick up confounding regional and industry factors or aggregate time trends. The paper also addresses the problem that the root cause of disability enrollment may be hidden in events that took place many years prior to actual entry into permanent disability. We show that social security careers ending in permanent disability are often extremely long and intricate. Identification of the triggering causes therefore requires long and detailed labor market histories for the population at risk. In order to identify the impacts of, e.g., job loss on the subsequent probability of becoming a disability pensioner, we either have to take into account that the outcome may materialize long after its cause, or we have to examine outcomes that materialize closer in time to their cause, but are highly correlated to the subsequent risk of permanent disability. In this paper we pursue both these strategies; the former by examining entry into permanent disability up to six years after displacement, and the latter by examining entry into temporary disability programs and withdrawal from the labor market.

Our key finding is that disability and non-participation risks are indeed significantly affected by exogenous change in employment opportunities. Some of the estimated effects are large from an economic viewpoint, particularly for men. Our most reliable indicator for individual displacement is full-time employment in a firm which is going to close down due to bankruptcy during the next four years. Holding such a job raises, on average, the risk of entering permanent disability during the upcoming six-year period by 2.1 percentage points for male employees and 1.3 percentage points for female employ- 
ees, when compared to holding a job in a stable firm. Taking into account that the risk of job loss is present even in stable firms, we assess that displacement raises the permanent disability risk by as much as 2.6 percentage points (123 percent) for men and 1.6 percentage points (50 percent) for women, ceteris paribus. We infer that displacements alone account for fully 28 percent of all new disability benefit claims among males and for 13 percent among females in our data. Not surprisingly, we also find strong impacts on the propensity for non-participation. For men, the probability of being outside the labor force after four years increases on average by 9.0 percentage points (124 percent) as a result of exogenous displacement. For women, the probability rises by 12.4 percentage points (100 percent). Employees' disability and non-participation propensities are also affected by more moderate downsizing processes and even by reductions in firm profitability without any downsizing. In addition, employment opportunities outside the current workplace play a significant role. A one standard deviation deterioration in local education/industryspecific labor market tightness (conditional on aggregate labor market tightness) raises the probability of entering permanent disability by around 0.4 percentage point (14 percent) for men and 0.5 percentage point (also 14 percent) for women.

The causal relationship between employment opportunity and disability propensity will to a certain extent reflect that job loss and unemployment entail adverse health consequences; see Kasl and Jones (2002) for a recent survey. In particular, our results show that for male employees displacement raises the mortality rate over a six-year period by 34 percent. Our data therefore support recent evidence from Sweden and the United States showing substantial adverse effects of displacement of mortality risk (Eliason and Storrie, 2009b; Sullivan and von Wachter, 2009). We furthermore find that a 
general worsening of local industry-specific employment opportunities tends to raise mortality among men.

The causal effects of displacement on disability and non-participation propensities presented in this paper are an order of magnitude larger than comparable effects reported in the Rege et al. (2009) and Huttunen et al. (2010) studies. We provide evidence that this disparity largely stems from differences in the operational definition of "displacement.” While the findings of the prior studies are based on mass layoffs identified from employment registers alone (with, as noted by the authors, the risk of misclassification in cases of reorganizations, demergers, and takeovers), the mass layoffs exploited in this paper are identified on the basis of auxiliary information taken from bankruptcy proceedings. This turns out to reduce the attenuation bias otherwise associated with the purely register-based approach. We conclude that employment opportunities have large effects on disability insurance utilization and that there in fact exists a considerable "grey area" between unemployment and disability program utilization in Norway.

\section{Institutional background and data}

Workers in Norway are insured against loss of work capacity from health impairment. Social insurance is compulsory and comprises sickness absence benefits, rehabilitation benefits, and disability pension. During sickness absences, the benefit replacement rate is 100 percent. Sickness absence benefits cannot be paid out for more than 12 months, however. The replacement ratio associated with subsequent rehabilitation benefits or disability pension is typically around 66 percent. Rehabilitation benefits are temporary (normally 1-3 years), and are paid out in connection with medical and/or vocational rehabilitation attempts. Disability pension is in practice a permanent benefit (lasting until the 
standard retirement age of 67), as the outflow from disability pension to self-supporting employment is negligible. Except for very short sickness absence spells (less than four days), all social insurance payments require that the health impairment is certified by a physician. In more serious cases, the application may also be assessed by independent physicians appointed by the social security administration (SSA). In any case, it must be certified that health impairment is the main cause for the loss of work capacity. There is no room for taking the individual's general employment opportunities into account, and it is explicitly stated in the legislation that social or economic problems do not qualify for disability benefits. The economic incentives embedded in the social insurance replacement ratios were stable during the time period covered by this paper, although the period covers some attempts at tightening gate-keeping, particularly for disability pensions; see Bratsberg et al. (2010a) for details.

The employer is responsible for covering sickness insurance payments during the first 16 days of the sickness absence spell. For longer spells and for permanent disability, the costs are covered in full by the public purse. There is no experience rating; hence there are limited pecuniary costs for firms associated with their employees utilizing longterm sickness or disabled. In fact, when a firm has redundant labor, but finds it difficult to lay off workers due to employment protection regulations, an employee's transition to long-term sickness absence or disability may be profitable for the firm.

The data we use in this paper consist of three parts. The first part contains a detailed account of individual labor market and social security event histories from 1992 to 2007, linked with comprehensive information about each individual. The second part contains a description of firms in terms of their employee composition and economic per- 
formance. Indicators for economic performance are constructed from annual audited accounting data, which all limited liability firms in Norway are required to make public. The third part contains information about the nature of firm closures. These data are collected from the Norwegian bankruptcy court system. A generic problem facing research based on administrative employer-employee data is to distinguish genuine mass layoffs from “spurious” layoffs, whereby a firm appears to downsize or close down while in reality it splits into smaller entities, merges with another company, or reorganizes in other ways. A strategy pursued in the existing literature (Fevang and Røed, 2006; Henningsen and Hægeland, 2008; Rege et al., 2009) is to interpret a mass layoff as "spurious" if a relatively large fraction of the workers make a transition to the same "new firm." But this strategy obviously will fail to identify a spurious layoff that splits the workforce, e.g., when a large firm is reorganized into several smaller entities. Thresholds for the fraction of workers moving together also yield awkward results for smaller firms. In the present paper, we exploit the additional information collected from bankruptcy courts to distinguish explicitly between closures due to bankruptcy, closures due to voluntary liquidation, and takeovers (with or without a bankruptcy).

A particular problem arising in attempts to identify the causal effect of employment opportunities on subsequent disability insurance claims is the long and variable time lags that may occur between the presumed cause and its observed effect. When granting a new disability pension, the social security administration (SSA) determines a "disablement date.” This date is meant to reflect the time at which the individual was originally subjected to a health-impairment responsible for the loss of at least 50 percent of work capacity. Since the size of the disability benefit is computed on the basis of earnings up to 
the time of disablement, the disablement date will be important for the level of benefits; hence its determination is likely to involve some considerate judgment. On the basis of recorded disablement dates in our data, we find that the disablement on average occurs three years before entry into the permanent disability benefit program. The variation across individuals is large, however, and for 15-20 percent of claimants it takes more than five years from the date of disablement until entry into permanent disability. The typical duration from disablement to disability pension uptake also varies significantly over time, primarily reflecting variation in policy makers' efforts to curb the inflow to permanent disability. To illustrate, in our data the average "waiting time" fell from 38 months for 1997 entrants to 32 months for 2000 entrants, after which it again rose to 36 months for 2003 entrants to permanent disability (we do not have comparable disablement date statistics for later entrants).

The SSA determination of the disablement date will involve some subjective judgment. Many disability entrants have long histories of labor market difficulties, often with combinations of unemployment and health problems. In these cases, it is difficult to identify a particular triggering event. Figure 1 displays the employment and social security histories - month by month - during the 12 -year period prior to permanent disability enrollment for men and women age 30 or older who entered the program in 2005. Almost one quarter of this group received social security transfers such as unemployment benefits as long as 12 years prior to their entry into permanent disability. Visible signs of health problems in the group as a whole, in form of declining employment rates and corresponding increases in the proportion claiming temporary health benefits, appear around six years before disability entry. (Here, temporary health benefits cover benefits paid 


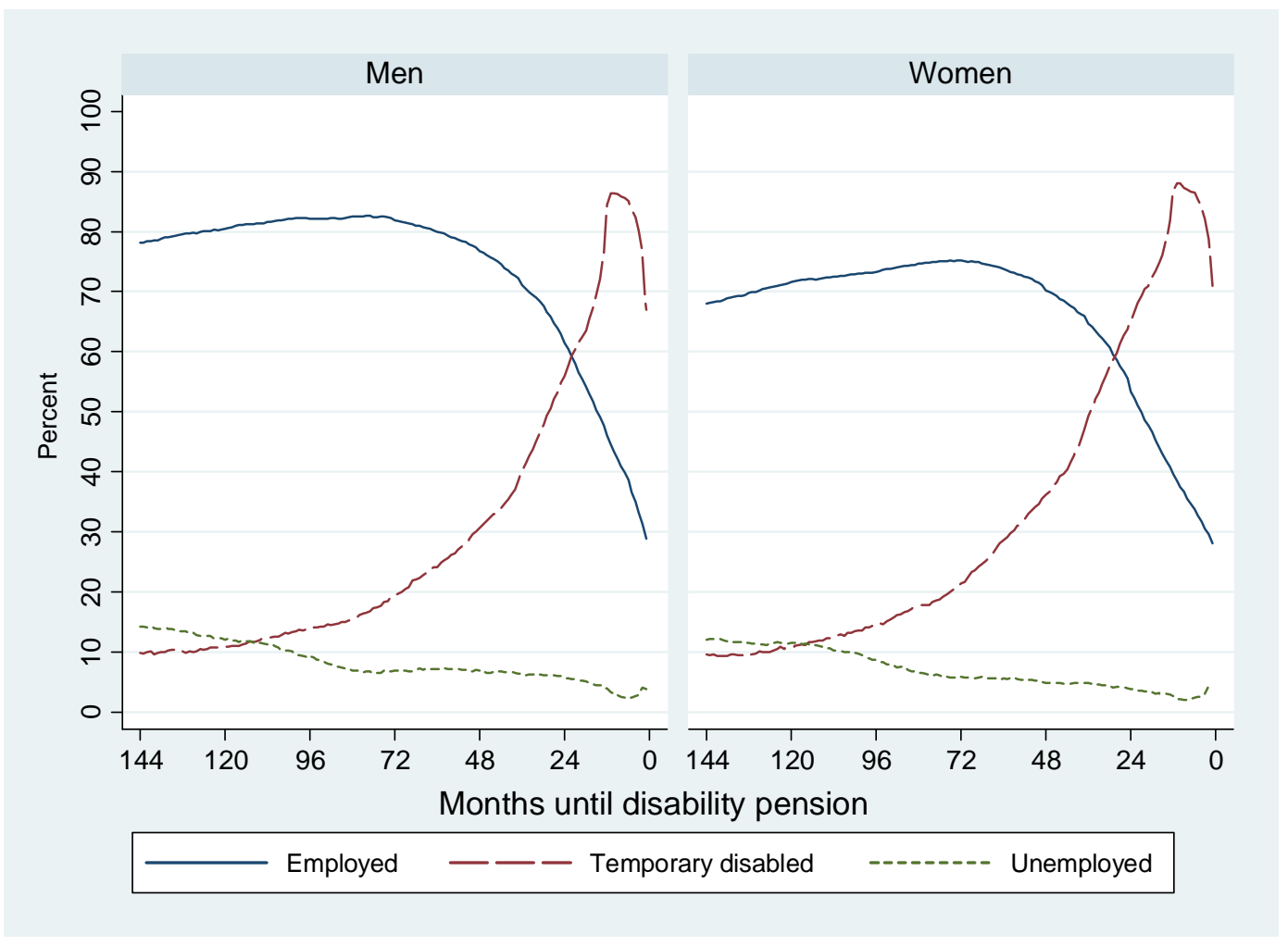

Figure 1. Past labor market states of 2005 permanent disability entrants.

Note: States are not mutually exclusive, as disability and unemployment may be partial and combined with some employment. Populations consist of 13,194 men and 15,993 women aged 30 or above who entered permanent disability in 2005.

during spells of medical or vocational rehabilitation and long-term sickness leaves.) Three years before entry into permanent disability, around 40 percent of the men and 50 percent of the women claimed temporary disability benefits. These patterns show that the road to permanent disability can be long and winding - often involving unemployment spells as well as periods on temporary health benefits - and that very few cases are "straightforward" in the sense that there is a once-and-for-all health shock leading quickly and directly to a disability pension. ${ }^{2}$

\footnotetext{
${ }^{2}$ The apparent decline in temporary disability just before entry into permanent disability displayed in Figure 1 mirrors the occurrence of a "benefit vacuum" period after temporary disability insurance options are exhausted, but before the application for permanent disability benefits has been approved.
} 


\section{The effect of employment opportunities on entry into disability}

\subsection{Methodology}

To allow for long time lags between employment opportunity shocks (the presumed cause) and entry into permanent disability (the possible effect), we have structured our dataset into three four-year time periods, starting at the end of the base years of 1993, 1997, and 2001, respectively. We condition the analysis on workers holding a full-time job on January $1^{\text {st }}$ following the base year. In addition, we exclude workers with recent social insurance spells and drop from the samples those who received social security benefits for more than six months during the prior two years. We then examine the probability of making transitions into permanent disability as well as into states that involve a high risk of subsequent transition to disability, as functions of, inter alia, exogenous change in employment opportunities. We limit the analysis to employees in private sector single-plant firms with more than 10 employees and for which we have access to audited accounting data (which includes all limited liability firms). ${ }^{3}$ We also limit attention to individuals who were between 20 and 63 years of age in the base year and who resided in Norway throughout the analysis period. All analyses are conducted separately for men and women.

We focus on three alternative outcome measures for the individual:

\footnotetext{
${ }^{3}$ A key to interpretation of our results is that workplace events can be considered exogenous with respect to the behavior of the individual employee. Since this assumption may be questionable for small workplaces, below we also present results based on samples of workers in large firms (more than 50 employees) to examine the robustness of our findings. The reason why we restrict attention to single-plant firms is that accounting and closure/takeover data are available at the company level. Hence, the accounting and closure data can be directly matched to workplace data for single-plant firms only. Finally, by focusing on single-plant firms we avoid complications caused by within-firm job transfers following plant closures (Huttunen et al., 2010).
} 


\begin{tabular}{lccc|ccc}
\hline \multicolumn{7}{c}{ Table 1. Analysis populations and the distribution of outcomes. } \\
\hline & 1993 & 1997 & 2001 & 1993 & 1997 & 2001 \\
Base year: & 130786 & 189703 & 203781 & 44549 & 59272 & 70373 \\
Observations & 9.2 & 12.6 & 13.9 & 14.4 & 19.2 & 21.3 \\
$\begin{array}{l}\text { Disability (temporary or permanent) } \\
\quad \text { during next 4 years (\%) }\end{array}$ & 7.8 & 10.6 & 11.1 & 14.2 & 16.8 & 17.1 \\
$\begin{array}{l}\text { Out of labor force 4 years later (\%) } \\
\text { Permanent disability within 6 years (\%) }\end{array}$ & 3.0 & 3.1 & 2.8 & 3.9 & 4.1 & 3.4 \\
\hline
\end{tabular}

1. Whether on disability — temporary or permanent—during the four-year period following the base year.

2. Whether outside the labor force four years after the base year. ${ }^{4}$

3. Whether entered permanent disability within six years of the base year.

Table 1 lists the size of the analysis populations and their distribution of outcomes. Comparing the three periods, we note that the incidence of permanent disability rose somewhat between the first and the second period, after which it declined to a level below that of the first period. The incidence of temporary (and permanent) disability rose sharply throughout the three periods; for women it increased quite dramatically, from 14.4 percent in the $1994-97$ period to 21.3 percent in the $2002-5$ period. We interpret the implicit shift from permanent to temporary disability in the third period as reflecting attempts by the Social Security Administration of curbing inflows into permanent disability through more ambitious rehabilitation attempts; see Section 2.

\footnotetext{
${ }^{4}$ Temporary disability is measured as having spells of medical or vocational rehabilitation or at least six months of long-term sickness leaves during the four-year interval. Being outside the labor force after four years is defined as either 1) having annual earnings or self-employment income below 144,000 NOK (2009 currency; approx 23,000 USD) during the last calendar year, 2) receiving permanent disability or rehabilitation benefits in the month of December that year, or 3) receiving long-term sickness benefits in December and for at least six months out of four-year period ending that month.
} 
In order to investigate empirically the impact of employment opportunities on the likelihood of becoming a disability benefit claimant, we need observed variation in employment opportunities that is exogenous with respect to each individual's disability propensity. We have identified three potential sources of such variation. Two of these operate at the workplace level, and consist of mass layoffs and variation in firm profitability, respectively. The third operates primarily at the county-by-occupation level, and consists of fluctuations in demand for the type of labor that the worker has to offer outside the present employer. While a mass layoff will have a very direct effect on the displaced workers' employment opportunities, we hypothesize that poor (or deteriorating) firm performance may put pressure on employees to quit "voluntarily" and/or to claim disability benefits of some kind; see Section 2. Fluctuations in local labor demand impinge on the employment opportunities for anyone searching for a new job.

In this setting, true exogeneity of workplace-specific employment opportunities might be questioned since the quality of a firm's employees will affect its economic performance and, hence, the likelihood of laying off workers. Moreover, firm-specific employment opportunities may correlate with other disability risk factors, related to, e.g., occupation and work. We address these possible problems by applying extensive controls for potentially confounding factors, by evaluating differences in employee composition between different types of firms, and through extensive robustness checks of our findings with respect to the composition of the analysis population. These checks include analyses where we focus on large firms only as reverse causality is more likely to be a concern in small firms. 
For mass layoffs, we have chosen a forward-looking setup, in the sense that we assess the impacts of closure and downsizing events that occur over a four year period after the base year. This is motivated by the idea that "early leavers” may have started the search for a new job in response to information about an impending mass layoff, implying that workers employed at the time of displacement already are highly selected; see Kuhn (2002) for a discussion. The downsizing indicators are computed in a similar fashion as in Rege et al. (2009, p. 764), i.e., as the percentage change in the number of fulltime equivalent workers between the start of each period and the date exactly four years later. ${ }^{5}$ When a workplace is downsized by 100 percent, we have - in contrast to previous studies - collected direct information on the reason why this happened, i.e., whether it resulted from a bankruptcy, a voluntary liquidation, or a takeover. Firms' profitability is measured by the annual rate of return on invested capital. We include both initial profitability (in the base year) and the change in profitability over the next four years as explanatory variables in our models.

In order to extract and isolate exogenous variation in local labor market tightness, we start out by constructing two individual and time-specific tightness indices; one reflecting the probability of becoming unemployed, the other reflecting the probability of finding a new job given that unemployment occurs. Both indices are computed on the basis of auxiliary (logit) regression models. To be precise, let $u_{i t}=1$ if person $i$ becomes unemployed in period $t$ and let $e_{i t}=1$ if the unemployed person finds new work within one year. We then set up the following models:

\footnotetext{
${ }^{5}$ Note that we do not exploit information on individual layoffs in order to avoid complications from selection bias in cases where some workers are retained by the firm (Henningsen and Hægeland, 2008).
} 


$$
\begin{aligned}
& \operatorname{Pr}\left(u_{i t}=1\right)=l\left(\phi_{t}+x_{i t} \varphi_{t}\right), \\
& \operatorname{Pr}\left(e_{i t}=1 \mid u_{i t}=1\right)=l\left(\psi_{t}+x_{i t} \pi_{t}\right), \\
& t=1994-1996,1998-2000,2002-2004,
\end{aligned}
$$

where $x_{i t}$ includes a large number of individual characteristics (to be explained below) including type of work (educational attainment and industry) and county of residence, and $l(a)=\exp (a)[1+\exp (a)]^{-1}$. Based on these regressions we compute for all individuals and each of the three periods the predicted (linear) unemployment and reemployment propensity indices, $u_{i t}^{*}=\hat{\phi}_{t}+x_{i t} \hat{\varphi}_{t}$ and $e_{i t}^{*}=\hat{\psi}_{t}+x_{i t} \hat{\pi}_{t}{ }^{6}$ Now, these indices are by construction functions of individual covariates and will, at face value, not be independent of the error term in a statistical model of individual disability or withdrawal propensity. As we explain below, we will deal with this endogeneity problem by controlling for $x_{i t}$ in all analyses where $\left(u_{i t}^{*}, e_{i t}^{*}\right)$ appear as explanatory variables, in essence isolating the variation in labor market opportunities that arise from time-varying effects of individual characteristics (in particular education, industry, and region).

Table 2 provides a descriptive overview of our analysis populations and the variables designed to represent change in individual employment opportunities. Males are strongly overrepresented in the dataset, reflecting our focus on full-time employees in the private sector. Workplace turbulence (in form of downsizing, closure, or takeover) generally increased from the first to the second period, and then declined slightly again in the third period. An important exception from this pattern is the bankruptcy rate, which increased significantly in both periods. Another important pattern to emerge from Table 2

\footnotetext{
${ }^{6}$ The two indices are designed to measure labor market tightness in the first three years of each four-year period. We do not include the fourth year for the reason that labor market tightness is likely to affect the three outcome measures with some time lag.
} 


\begin{tabular}{|c|c|c|c|c|c|c|c|c|}
\hline \multirow[b]{2}{*}{ Base year: } & \multicolumn{4}{|c|}{ Men } & \multicolumn{4}{|c|}{ Women } \\
\hline & All & 1993 & 1997 & 2001 & All & 1993 & 1997 & 2001 \\
\hline Observations & 524270 & 130786 & 189703 & 203781 & 174194 & 44549 & 59272 & 70373 \\
\hline Age & 39.4 & 39.3 & 39.1 & 39.9 & 38.7 & 37.9 & 38.6 & 39.3 \\
\hline Education & & & & & & & & \\
\hline Compulsory & 24.3 & 26.8 & 24.8 & 22.2 & 24.4 & 27.9 & 24.9 & 21.7 \\
\hline Secondary & 56.1 & 55.2 & 56.6 & 56.3 & 54.1 & 56.7 & 55.4 & 51.4 \\
\hline College/University & 19.1 & 17.6 & 18.2 & 20.9 & 21.0 & 14.9 & 19.3 & 26.3 \\
\hline $\begin{array}{l}\text { Earnings in base year } \\
\text { (1000 NOK, 2009-value) }\end{array}$ & 402 & 373 & 389 & 434 & 297 & 262 & 287 & 327 \\
\hline Percent subject to & & & & & & & & \\
\hline $10-20 \%$ downsizing & 9.3 & 6.9 & 10.4 & 9.8 & 9.9 & 8.6 & 10.2 & 10.5 \\
\hline 20-35 \% downsizing & 8.9 & 5.3 & 10.5 & 9.6 & 10.1 & 7.4 & 11.5 & 10.6 \\
\hline 35-99\% downsizing & 14.0 & 9.8 & 15.5 & 15.4 & 15.6 & 12.7 & 18.3 & 15.0 \\
\hline Closure w bankruptcy & 2.6 & 1.4 & 2.6 & 3.2 & 1.8 & 1.0 & 1.8 & 2.3 \\
\hline Liquidation & 5.0 & 4.7 & 5.7 & 4.5 & 5.6 & 5.1 & 6.6 & 5.2 \\
\hline Takeover & 10.0 & 9.3 & 12.7 & 7.9 & 10.9 & 10.6 & 13.5 & 9.0 \\
\hline Return on capital & 0.072 & 0.079 & 0.091 & 0.055 & 0.072 & 0.087 & 0.086 & 0.050 \\
\hline Change return on capital & -0.008 & -0.001 & -0.047 & 0.023 & -0.007 & -0.012 & -0.042 & 0.026 \\
\hline Risk of unemployment & 14.9 & 14.9 & 13.2 & 16.4 & 15.9 & 16.7 & 14.1 & 17.0 \\
\hline Prob. of reemployment & 68.8 & 73.8 & 70.8 & 64.5 & 58.1 & 57.0 & 61.8 & 56.2 \\
\hline
\end{tabular}

Note: Individual characteristics (age, education, earnings) are measured in base year, while firm downsizing and closure indicators refer to four-year period following the base year.

is that takeovers make up a majority of the firm closures in the data. Around 18 percent of male and female full-time employees in our dataset work in a firm that "disappears" over the next four years, ${ }^{7}$ but almost 60 percent of these jobs are subject to a firm takeover or acquisition and are therefore less likely to entail displacement than jobs in firms that go bankrupt.

For our three ultimate outcome measures, we estimate the following models:

$$
\operatorname{Pr}\left(y_{i j t}=1\right)=l\left(\alpha_{j t}+x_{i t} \beta_{j}+z_{i t} \delta_{j}+u_{i t}^{*} \gamma_{j}+e_{i t}^{*} \lambda_{j}\right),
$$

${ }^{7}$ In addition, there are some jobs in our dataset that seemingly disappear because of mismatches between firm identifiers in the two main data sources. Specifically, 1.16 percent of males and 1.25 percent of females work in firms that disappear from the employer-employee data during the upcoming four years but do not close down according to the accounting data; and 0.98 and 1.36 percent work in firms that vanish from the accounting data but not from the employer-employee data. We include these jobs in our analyses, but mark the observations as firm-identifier mismatches. 
where $y_{i j t}(j=1,2,3)$ are three dichotomous outcome indicators for individual $i$ corresponding to the three time periods $t$ as defined in Table 1 . The vector $z_{i t}$ contains all workplacespecific covariates such as initial firm size, downsizing, closure, turnover, and profitability. ${ }^{8}$ As explained above, the vector of individual characteristics $\left(x_{i t}\right)$ contains information about the (initial) type of work and county of residence. Since we do not have direct information about occupation, type of work is proxied by a combination of educational attainment and industry (resulting in 21 different job type categories). In addition, we include information about age (44 different age classes), nationality (eight classes), work experience (six classes), initial log earnings and the change in log earnings from the prior year, initial family situation (i.e., marital status, number of children and labor market status of the spouse; 10 categories), county of residence (19 categories), and, for old workers, entitlement to early retirement programs. A complete listing of the explanatory variables $\left(x_{i t}, z_{i t}\right)$ is provided in the Appendix.

A key point to note is that the individual characteristics $\left(x_{i t}\right)$ used in Equation (2) are exactly the same as in Equation (1) and, hence, used to compute the risk of unemployment and reemployment indeces, $u_{i t}^{*}$ and $e_{i t}^{*}$. This implies that the two variables are perfectly collinear with $x_{i t}$ in any single time period in Equation (2). Note, though, that coefficients of Equation (1) carry a t-subscript while those of Equation (2) do not. We have deliberately constructed the variables this way to ensure that it is only idiosyncratic change in employment opportunities over time that identify the effect on the risk of dis-

\footnotetext{
${ }^{8}$ For firms that close down during the period, we set the change in profitability equal to the sample mean in order to keep the observation in the analysis.
} 
ability and non-participation. The key source of identification is that different industries were subject to different cyclical fluctuations during the three observation periods. For example, while employment opportunities in the manufacturing industries and in agriculture declined, particularly for workers with low education, the employment opportunities in retail, restaurants, and tourism improved. An additional source of identification is that the cyclical fluctuations in labor demand vary across regions. Thus, an exclusion restriction is that local business cycle fluctuations have no direct effects, but affect disability and labor force withdrawal only through the variation they create in individual unemployment and reemployment risks.

Since an important aim of this paper is to assess the extent to which individual displacement affects the risk of subsequent disability, we place considerable emphasis on the effects of working in a firm that is going to close down due to bankruptcy during the next four years. As Table 2 showed, in any of the three four-year intervals only between 1.0 and 3.2 percent of workers experienced a bankruptcy. This does not imply, however, that displacements are rare. According to Salvanes (1997), as many as 10 percent of Norwegian jobs are eliminated every year. We therefore expect displacement to be relatively common even in stable or growing firms. Table 3 shows how the downsizing and closure indicators correlate with subsequent incidences of registered unemployment (within the corresponding four-year downsizing/closure period) in our data. With unemployment incidence rates of 57 percent for men and 62 percent for women, entry into registered unemployment is indeed much higher among workers exposed to a bankruptcydriven closure than among other workers. It is nonetheless clear from the table that unemployment is relatively frequent regardless of type of downsizing event. The table also 


\begin{tabular}{|c|c|c|c|c|c|c|c|c|}
\hline & \multicolumn{4}{|c|}{ Men } & \multicolumn{4}{|c|}{ Women } \\
\hline & $\begin{array}{c}\text { Regis- } \\
\text { tered } \\
\text { unem- } \\
\text { ployed, } \\
4 \text { yrs } \\
(\%) \\
\end{array}$ & $\begin{array}{c}\text { Temp } \\
\text { or per- } \\
\text { manent } \\
\text { disabil- } \\
\text { ity, } 4 \\
\text { yrs (\%) }\end{array}$ & $\begin{array}{l}\text { Out of } \\
\text { labor } \\
\text { force } \\
\text { after } 4 \\
\text { yrs (\%) }\end{array}$ & $\begin{array}{c}\text { Perma- } \\
\text { nent } \\
\text { disabil- } \\
\text { ity, } 6 \\
\text { yrs (\%) }\end{array}$ & $\begin{array}{c}\text { Regis- } \\
\text { tered } \\
\text { unem- } \\
\text { ployed, } \\
4 \text { yrs } \\
(\%) \\
\end{array}$ & $\begin{array}{c}\text { Temp } \\
\text { or per- } \\
\text { manent } \\
\text { disabil- } \\
\text { ity, } 4 \\
\text { yrs (\%) }\end{array}$ & $\begin{array}{l}\text { Out of } \\
\text { labor } \\
\text { force } \\
\text { after } 4 \\
\text { yrs (\%) }\end{array}$ & $\begin{array}{c}\text { Perma- } \\
\text { nent } \\
\text { disabil- } \\
\text { ity, } 6 \\
\text { yrs (\%) }\end{array}$ \\
\hline No downsizing $(<10 \%)$ & 12.4 & 11.3 & 8.5 & 2.6 & 13.1 & 17.6 & 14.0 & 3.4 \\
\hline $10-20 \%$ downsizing & 17.9 & 13.1 & 11.3 & 3.4 & 19.1 & 20.1 & 16.9 & 4.0 \\
\hline $20-35 \%$ downsizing & 21.9 & 13.7 & 11.6 & 3.3 & 23.7 & 20.5 & 18.1 & 4.3 \\
\hline 35-99\% downsizing & 26.5 & 14.0 & 13.0 & 3.7 & 29.5 & 19.9 & 19.8 & 4.3 \\
\hline Closure w bankruptcy & 56.5 & 18.8 & 18.8 & 4.9 & 62.2 & 24.7 & 27.9 & 4.3 \\
\hline Liquidation & 19.6 & 10.5 & 10.4 & 2.6 & 25.3 & 18.5 & 17.6 & 3.5 \\
\hline Takeover & 20.0 & 11.6 & 10.9 & 2.7 & 21.6 & 19.8 & 16.5 & 4.4 \\
\hline
\end{tabular}

reveals that the prevalence of our disability and non-participation outcome measures are higher for workers that faced workplace restructuring than for workers in stable or growing firms, and that, at least for men, the bankruptcy category stands out with high future incidence rates of disability and labor force withdrawal.

To get a rough estimate of the overall level of displacements in our own data, we use the unemployment frequencies reported in Table 3 as a starting point. If we assume that all employees in the "closure with bankruptcy" category are actually displaced, we can infer that 56.5 percent of displaced male workers and 62.2 percent of displaced female workers register as unemployed during the four-year period in question. ${ }^{9}$ If we further assume that these unemployment registration propensities also apply to workers displaced from other (non-bankruptcy) firms, we can use the numbers listed in Table 3 to back out the total number of displaced workers in our data. Doing this exercise separately for men and women, we compute that 31 percent of both male and female employees in

\footnotetext{
${ }^{9}$ These are probably conservative estimates, as some employees in the bankruptcy bracket may have shifted to other firms (without any intermediate period of registered unemployment) for reasons that had nothing to do with the forthcoming bankruptcy.
} 


\begin{tabular}{lc|c|c|c}
\hline \multicolumn{4}{c}{ Table 4. Descriptive statistics by firm closure and downsizing status. } \\
\hline & $\begin{array}{c}\text { Closure w } \\
\text { bankruptcy }\end{array}$ & $\begin{array}{c}\text { Liquidation or } \\
\text { takeover }\end{array}$ & $\begin{array}{c}\text { Downsizing } \\
\text { ing(<10\%) }\end{array}$ \\
\hline Outcome (\%) & 19.9 & 14.1 & 15.3 & 12.8 \\
$\quad$ Temporary or permanent disability & 20.5 & 12.7 & 13.7 & 9.9 \\
$\quad$ Out of labor force & 4.8 & 3.3 & 3.7 & 2.8 \\
$\quad$ Permanent disability & 1.5 & 1.4 & 1.5 & 1.4 \\
Sickness absence yr before base yr (\%) & & & & \\
& 18.9 & 26.8 & 26.5 & 23.9 \\
Female (\%) & 38.1 & 38.8 & 39.6 & 39.3 \\
Age & & & & \\
Education & 28.4 & 24.2 & 25.1 & 23.8 \\
$\quad$ Compulsory & 56.7 & 54.5 & 55.1 & 56.1 \\
$\quad$ Secondary & 14.1 & 20.9 & 19.3 & 19.6 \\
$\quad$ College/University & 346 & 379 & 374 & 378 \\
Earnings in base yr (1000 NOK, 2009) & 61.6 & 109.4 & 146.5 & 110.9 \\
Plant size & 16,462 & 107,409 & 195,047 & 379,546 \\
$\quad$ Number of workers (all three periods) & & & \\
\hline
\end{tabular}

our dataset are displaced over a four-year period. ${ }^{10}$ Even in the no-downsizing bracket $(<10 \%)$, we find that the four-year displacement rate is 22 percent for men and 21 percent for women. To the extent that we interpret the effects of working in a bankruptcyexposed firm - as opposed to working in a firm with no downsizing - as representing the causal effect of displacement, our estimates will thus clearly be subject to contamination bias (Heckman and Robb, 1985). We return to the issue of contamination bias in Section 3.2 below.

As stressed by Rege et al. (2009), the estimated impact of firm closure may be impacted by selection bias if workers in closing firms differ systematically from workers in continuing firms. Table 4 provides descriptive statistics for workers in firms that closed down due to bankruptcy and for workers in other firms. To check for possible ini-

${ }^{10}$ This number is only slightly below what would be expected on the basis of the 10 percent annual job elimination rate reported by Salvanes (1997), which - provided that the risk is independently distributed across individuals over time - yields a 35 percent cumulative displacement rate over a four-year period $\left(1-0.9^{4}\right)$. 
tial differences in the workers' health status, we report sickness absence rates for employees in closing, downsizing, and other firms in the year prior to the base year (calculated for the populations actually used in our analysis). The table reveals that the absence rate was slightly higher in bankruptcy and downsizing firms than in other firms. The difference is minor, however, when compared to the large differences in subsequent outcomes. To formally test for whether employees in closing firms had poorer health than employees in stable or growing firms even prior to the advent of the closing process, we estimate a separate model with past sickness absence as the dependent variable. The model is formulated exactly as the models we use for other outcome variables and include the same control variables (see Equation 2), and the dependent variable is set equal to unity if the employee had a long-term (at least 16 days) sickness absence spell in the year prior to the base year (otherwise zero). Results (not reported in tables) show that the estimated average marginal effect of working in a closing (bankruptcy) firm is equal to 0.48 percentage point for men ( $t$-value $=1.77$ ) and 0.12 percentage point for women (tvalue $=0.19$ ). Hence, although we cannot rule out minor ex ante health differences, there is no statistical evidence of poorer initial health in closing firms conditional on the variables that we use to explain future outcomes.

\subsection{Results from the baseline model}

Tables 5 and 6 present our key results regarding the impacts of employment opportunity on subsequent disability and non-participation for men and women, respectively. For ease of interpretation, we report average marginal effects (multiplied by 100); i.e., the mean percentage point impact of the explanatory variable on each of the three outcome probabilities. Average marginal effects are computed on the basis of relevant comparisons 
only, implying that for dummy variable sets with more than two categories, each category’s average marginal effect is calculated for observations belonging to the category in question and the reference category only; see Bartus (2005). A complete listing of estimated coefficients (with standard errors) is provided in the Appendix. ${ }^{11}$

As the tables show, employment opportunities have large and statistically significant effects on the disability and non-employment propensities. For both men and women, the probability of claiming permanent disability benefits after six years, and the likelihood of being out of the labor force after four years, rise significantly and monotonously with the level of workplace downsizing, ceteris paribus. All three outcome propensities decline significantly with the employer's economic performance and, at least for men, with improvements in local labor market tightness as captured by the risk of unemployment and re-employment variables.

As explained above, our most reliable indicator of exogenous displacement is the “closure with bankruptcy during the next four years” variable. As shown in Table 5, col. 3, such an event raises a male worker's probability of claiming permanent disability after six years by 2.1 percentage points, compared to working in a stable or growing firm. Given the large and variable time lags in entry into permanent disability described in Section 2, and since virtually all permanent disability claims are preceded by extended periods on

${ }^{11}$ In order to account for any covariance between employees working at the same establishment (and to correct for Moulton (1986) bias), we cluster standard errors within firm-by-period cells. Were we instead to cluster at the establishment level (to also account for any serial correlation across periods), standard errors would be slightly larger than those reported in tables. To illustrate, the standard error of the coefficient of the bankruptcy variable in the male permanent disability logit equation becomes 0.06118 (21,332 cluster units) as opposed to 0.06082 (34,620 clusters) as reported in the appendix. Note also that the three periods will contain multiple observations of some of the workers in our sample (the baseline samples consist of 524,270 observations of 347,748 males and 174,194 observations of 128,391 females). Using clustering to account for serially correlated errors among individuals with multiple observations raises standard errors by an even smaller amount than clustering within firms. 
Table 5.

Estimated percentage point impacts of employment opportunities on disability and non-participation. Men, full-time workers.

Average marginal effects (AME) with robust standard errors (RSE).

\begin{tabular}{|c|c|c|c|c|c|c|}
\hline & \multicolumn{2}{|c|}{$\begin{array}{l}\text { Temporary or perma- } \\
\text { nent disability }\end{array}$} & \multicolumn{2}{|c|}{ Out of labor force } & \multicolumn{2}{|c|}{ Permanent disability } \\
\hline & $A M E$ & RSE & $A M E$ & RSE & AME & $R S E$ \\
\hline No downsizing $(<10 \%)$ & Ref. & & Ref. & & Ref. & \\
\hline 10-20 \% downsizing & 0.50 & 0.23 & 1.51 & 0.36 & 0.38 & 0.09 \\
\hline 20-35 \% downsizing & 1.06 & 0.21 & 1.66 & 0.22 & 0.47 & 0.10 \\
\hline 35-99\% downsizing & 1.72 & 0.21 & 2.95 & 0.27 & 0.90 & 0.10 \\
\hline Closure with bankruptcy & 4.77 & 0.54 & 7.09 & 0.48 & 2.05 & 0.24 \\
\hline Liquidation & 0.78 & 0.30 & 3.08 & 0.32 & 0.68 & 0.15 \\
\hline Takeover & 0.03 & 0.20 & 0.37 & 0.26 & 0.06 & 0.09 \\
\hline Initial rate of return on capital & -0.14 & 0.08 & -0.61 & 0.19 & -0.11 & 0.03 \\
\hline Change in return on capital ${ }^{\#}$ & -0.23 & 0.08 & -0.42 & 0.15 & -0.07 & 0.03 \\
\hline Risk of unemployment index & 1.67 & 0.30 & -0.01 & 0.29 & 0.46 & 0.13 \\
\hline Prob of reemployment index ${ }^{\#}$ & -0.75 & 0.24 & -1.56 & 0.21 & 0.06 & 0.09 \\
\hline Percent with outcome $=1$ & & & & & & \\
\hline
\end{tabular}

"Marginal effects are calculated as the effect of a one standard deviation change in the explanatory variable. Number of observations: 524,270. Standard errors are clustered within 34,620 firm-by-period cells.

The following controls are included in the regressions (number of categories for categorical variables in parentheses): Education/industry (21), age (44), nationality (8), actual work experience (6), initial level and change in log earnings, family situation (10), county of residence (19), size of municipality (5), firm size (4), employee turnover in base year (5), time period (3), firm-identifier mismatch (3), and, for old workers, entitlement to early retirement programs (2).

temporary disability benefits and/or by self-supported periods outside the labor force, it is of interest to examine the impacts on these outcomes as well. According to the estimates in Table 5, a bankruptcy raises a male full-time worker’s probability of claiming either temporary or permanent disability by 4.8 percentage points and the probability of labor force withdrawal (measured four years after the base year) by 7.1 percentage points. These large additional flows into temporary disability and non-participation show that the 2.1 percentage points rise in permanent disability identified after six years does not capture the full effect of displacement. 
Table 6.

Estimated percentage point impacts of employment opportunities on disability and non-participation. Women, full-time workers.

Average marginal effects (AME) with robust standard errors (RSE).

\begin{tabular}{|c|c|c|c|c|c|c|}
\hline & \multicolumn{2}{|c|}{$\begin{array}{c}\text { Temporary or perma- } \\
\text { nent disability }\end{array}$} & \multicolumn{2}{|c|}{ Out of labor force } & \multicolumn{2}{|c|}{ Permanent disability } \\
\hline & $A M E$ & RSE & $A M E$ & RSE & $A M E$ & $R S E$ \\
\hline No downsizing $(<10 \%)$ & Ref. & & Ref. & & Ref. & \\
\hline 10-20 \% downsizing & 1.17 & 0.38 & 1.56 & 0.37 & 0.19 & 0.17 \\
\hline 20-35 \% downsizing & 1.08 & 0.37 & 2.09 & 0.37 & 0.41 & 0.18 \\
\hline 35-99\% downsizing & 0.73 & 0.32 & 3.98 & 0.35 & 0.71 & 0.16 \\
\hline Closure with bankruptcy & 4.44 & 0.81 & 9.80 & 0.89 & 1.28 & 0.41 \\
\hline Liquidation & 1.61 & 0.50 & 4.61 & 0.55 & 0.81 & 0.24 \\
\hline Takeover & 1.42 & 0.35 & 0.93 & 0.34 & 0.26 & 0.15 \\
\hline Initial rate of return on capital ${ }^{\#}$ & -0.63 & 0.13 & -0.49 & 0.14 & -0.14 & 0.06 \\
\hline Change in return on capital ${ }^{\#}$ & -0.31 & 0.13 & -0.39 & 0.14 & -0.10 & 0.06 \\
\hline Risk of unemployment index & 1.73 & 0.46 & -0.24 & 0.42 & 0.29 & 0.20 \\
\hline Prob of reemployment index ${ }^{\#}$ & -0.42 & 0.46 & -2.27 & 0.41 & -0.25 & 0.17 \\
\hline Percent with outcome $=1$ & & & & & & \\
\hline
\end{tabular}

"Marginal effects are calculated as the effect of a one standard deviation change in the explanatory variable. Number of observations: 174,194. Standard errors are clustered within 29,700 firm-by-period cells. See also notes to Table 5 .

Table 6 demonstrates that the effects of job loss on disability and nonparticipation are large for women as well, though generally smaller than those for men when measured relative to the average outcome within gender. For a female full-time worker, a bankruptcy raises the disability risk by around 1.3 percentage points. The risk of temporary or permanent disability rises by around 4.4 percentage points, while the probability of non-participation goes up by 9.8 percentage points.

The estimates listed in Tables 5 and 6 show the effect of, e.g., working in a bankruptcy firm as opposed to a stable or growing firm, and not the effect of displacement per se. We can nevertheless use the estimated effects to evaluate the underlying causal impacts of displacement. As we argued in Section 3.1, displacement is relatively common even in stable and moderately downsizing firms. This implies that the estimated effects of 
closure with bankruptcy reported in Tables 5 and 6 in fact underrate the causal effects of displacement. Adjusting the point estimates for contamination bias caused by inclusion of treated (i.e., displaced) employees in the non-treatment (no downsizing) group, we find that displacement on average raises the permanent disability propensity for men by 2.6 percentage points (123 percent) and for women by 1.6 percentage points (50 percent). ${ }^{12}$ Likewise, the risk of temporary or permanent disability rises by 6.1 percentage points (60 percent) for men and by 5.7 percentage points (33 percent) for women following job loss. Finally, accounting for contamination bias, displacement raises the non-participation propensity by 9.0 percentage points (124 percent) for men and by 12.4 percentage points (100 percent) for women. If we assume that these effects are representative for all displaced workers in our dataset, we infer that displacements account for fully 28 percent of all new permanent disability benefit claims among males and for 13 percent among females. ${ }^{13}$ Similarly, we find that for men (women), displacements account for 28 (24) percent of transitions to non-employment and for 16 (9) percent of transitions to temporary or permanent disability.

Local industry-specific labor market conditions significantly affect transitions into disability and non-participation (conditional on aggregate labor market conditions). For example, a one standard deviation increase in the risk of unemployment (around 10 per-

\footnotetext{
${ }^{12}$ We adjust for contamination bias by dividing the estimated average marginal effect of "closure with bankruptcy" with the estimated fraction of non-displaced workers in non-downsizing firms. To illustrate, for men the adjusted effect is calculated as $2.05 /(1-0.22)=2.63$, where 0.22 is the estimated fraction of displacement over the four-year interval among males in non-downsizing firms; see Section 3.1. We compute the counterfactual disability entry rate - the rate that would have prevailed in the absence of any displacements - as the actual entry rate minus the product of the estimated average effect of displacement and the computed overall rate of displacements.

${ }^{13}$ The assumption that closure-generated layoffs have the same impact as other layoffs is of course questionable. For example, congestion effects in local labor markets may imply that mass layoffs have larger adverse consequences than other layoffs. On the other hand, more selective layoffs may carry a stigma and thus serve as an adverse signal about an employee's productivity; see Gibbons and Katz (1991).
} 
centage points) raises the likelihood of entry into temporary or permanent disability by 1.7 percentage points for both men and women. A negative shock to the local labor market resulting in higher unemployment risk and reduced likelihood of reemployment (both of a magnitude of one standard deviation), is predicted to raise the inflow rate to permanent disability by 0.4 percentage point (i.e., 14 percent) for men and 0.5 percentage point (also 14 percent) for women. While the risk of unemployment incidence has a relatively large effect on disability entry, labor force withdrawal is more strongly affected by the probability of reemployment.

The economic performance of surviving firms - as measured by the annual return on their capital base - also has statistically significant effects on transitions into disability and non-participation (conditional on the level of downsizing). Although the effects on disability claims are moderate in size, they are far from negligible. For example, a onestandard-deviation deterioration in initial profitability and its four-year change will raise the female entry rate into temporary or permanent disability by approximately 1 percentage point $(0.63+0.31)$. The indication is that poor economic performance puts pressures on employees that, in turn, either trigger health problems or make it more difficult to maintain employment with a given health problem; see also Rege et al. (2009).

It is probable that the impact of employment opportunity varies across workers and over time, and also that there is an interaction effect between displacement/downsizing and local industry-specific labor market tightness. To examine these possibilities, we have estimated models that allow for heterogeneity in the effects of interest. Although not reported in tables, we find evidence that the adverse impacts of displacement are larger for old (above 50) than for young workers. While this is true for both disability and non- 
participation outcomes for men, it applies to the non-participation outcome only for women. We do not uncover statistical evidence showing that the impact of displacement has increased over time, although point estimates indicate a slight positive trend in the effect of displacement on disability propensity for women, with the female displacement effect becoming more similar to that of men. Not surprisingly, the effect of displacement on non-participation declines with the probability of reemployment. However, we do not find any corresponding interaction effect on the risk of entering disability.

\subsection{Robustness analyses}

Even though the results presented in Tables 5 and 6 account for a rich set of control variables, we cannot a priori rule out that employees in downsizing and closing firms differ systematically from employees in stable or growing firms. For example, the layoff process in closing firms may have started during or before the base year, leaving a selected group of employees in terms of unobserved disability risk. (Recall, however, that we failed to uncover initial differences in sickness absence rates between employees in closing and non-closing firms in Section 3.1.) Moreover, there is the concern of reverse causality: If many workers in a small firm become disabled, this may have detrimental effect on the firm's economic performance, and can - at least for small firms - even cause bankruptcy.

Tables 7 and 8 report the estimated average marginal effects of our employment opportunity variables from a number of robustness exercises. In column I, we first examine whether effect estimates for the workplace restructuring variables are impacted by inclusion of the firm profitability and local labor market tightness measures in the em-

pirical model. Because the change in profitability is not observed for firms that close 
down, and because the labor market tightness measures rely on certain exclusion restrictions, their presence might affect other coefficient estimates. Results in column I show that this is not the case-if anything, dropping these measures raise impact estimates slightly for the set of restructuring variables. Column II lists the estimated effects based on employees in the restricted sample of firms that did not downsize at all during the two years prior to the outcome period. If our results were driven by early sorting caused by an ongoing downsizing process, we would expect estimates to be sensitive to this sample condition. Column III presents estimates for employees in large firms only (more than 50 employees). If our results reflect reverse causality, the estimated impacts should drop significantly when we restrict the sample to employees in large firms. Columns IV-VI report estimates based on reduced samples with additional restrictions regarding recent social insurance history and stability of employment in the same firm. Again, if some adverse sorting process had taken place in downsizing/closing firms prior to our sample period, we would expect the estimated impacts to decline in these restricted samples.

Focusing on the estimated impacts of closure with bankruptcy on the disability and non-employment propensities, we note that our baseline results appear fairly stable across specifications. For women, all of the robustness specifications actually produce larger estimated impacts on permanent disability than what we found in the baseline model. For men, some of the robustness exercises yield stronger effects. Of particular interest is that the estimates listed in columns V-VI, where we restrict the sample to highseniority workers, exceed those from the baseline model, regardless of outcome measure and gender. With our ability to pinpoint the reason for firm closures, we have opted to 
Table 7.

Estimated percentage point impacts of employment opportunities on temporary or permanent disability and nonparticipation. Men, full-time

Average marginal effects (AME)- Point estimates.

\begin{tabular}{|c|c|c|c|c|c|c|}
\hline & $\begin{array}{c}I \\
\text { Omit profits } \\
\text { and labor } \\
\text { demand } \\
\text { indices } \\
\end{array}$ & $\begin{array}{c}\text { II } \\
\text { Firm size } \\
\text { stable last } \\
\text { two years }\end{array}$ & $\begin{array}{c}\text { III } \\
\text { More than } \\
50 \text { employ- } \\
\text { ees }\end{array}$ & $\begin{array}{c}I V \\
\text { No welfare } \\
\text { benefits } \\
\text { prior two } \\
\text { years }\end{array}$ & $\begin{array}{c}V \\
\text { Employed } \\
\text { in the same } \\
\text { firm prior } \\
\text { two years }\end{array}$ & $\begin{array}{c}\text { VI } \\
\text { Employed in } \\
\text { the same } \\
\text { firm prior } \\
\text { five years }\end{array}$ \\
\hline \multicolumn{7}{|c|}{ A) Temporary or permanent disability } \\
\hline $10-20 \%$ downsizing & 0.56 & 0.57 & 0.63 & 0.21 & 0.54 & 0.67 \\
\hline 20-35 \% downsizing & 1.15 & 1.09 & 0.94 & 0.62 & 1.03 & 1.08 \\
\hline 35-99\% downsizing & 1.85 & 1.68 & 1.45 & 1.34 & 1.70 & 2.17 \\
\hline Closure w bankruptcy & 4.99 & 4.57 & 4.05 & 4.53 & 6.15 & 6.87 \\
\hline Liquidation & 0.89 & 0.57 & -0.03 & 0.85 & 1.66 & 2.12 \\
\hline Takeover & 0.04 & -0.01 & -0.23 & 0.06 & 0.12 & 0.17 \\
\hline Return on capital & & -0.16 & -0.10 & -0.08 & -0.22 & -0.20 \\
\hline Chang in ret capital & & -0.25 & -0.11 & -0.16 & -0.27 & -0.12 \\
\hline Risk of unempl index & & 1.59 & 2.19 & 1.39 & 1.81 & 1.51 \\
\hline Prob of reempl index & & -0.81 & -0.32 & -0.62 & -0.70 & -0.87 \\
\hline Percent w outcome $=1$ & 12.22 & 12.18 & 12.49 & 8.44 & 12.65 & 12.87 \\
\hline \multicolumn{7}{|c|}{ B) Out of labor force } \\
\hline 10-20 \% downsizing & 1.65 & 1.28 & 1.70 & 1.28 & 1.42 & 1.50 \\
\hline 20-35 \% downsizing & 1.90 & 1.73 & 1.44 & 1.43 & 1.80 & 1.79 \\
\hline 35-99\% downsizing & 3.34 & 2.84 & 2.35 & 2.38 & 3.11 & 3.43 \\
\hline Closure w bankruptcy & 8.00 & 7.02 & 7.08 & 6.44 & 8.60 & 9.40 \\
\hline Liquidation & 3.52 & 2.96 & 1.77 & 2.64 & 4.16 & 5.38 \\
\hline Takeover & 0.42 & 0.43 & -0.02 & 0.48 & 0.49 & 0.54 \\
\hline Return on capital & & -0.45 & -1.11 & -0.61 & -0.79 & -0.94 \\
\hline Chang in ret capital & & -0.33 & -0.66 & -0.41 & -0.51 & -0.53 \\
\hline Risk of unempl index & & 0.10 & -0.44 & -0.06 & -0.46 & -0.90 \\
\hline Prob of reempl index & & -1.62 & -1.76 & -1.39 & -1.35 & -1.64 \\
\hline Percent w outcome $=1$ & 10.10 & 9.98 & 10.71 & 7.63 & 9.83 & 10.15 \\
\hline \multicolumn{7}{|c|}{ C) Permanent disability } \\
\hline 10-20 \% downsizing & 0.40 & 0.40 & 0.42 & 0.16 & 0.45 & 0.55 \\
\hline 20-35 \% downsizing & 0.50 & 0.46 & 0.43 & 0.25 & 0.57 & 0.68 \\
\hline 35-99\% downsizing & 0.96 & 0.82 & 0.95 & 0.69 & 1.22 & 1.67 \\
\hline Closure w bankruptcy & 2.20 & 1.83 & 2.47 & 1.81 & 2.96 & 3.71 \\
\hline Liquidation & 0.73 & 0.58 & 0.21 & 0.51 & 1.10 & 1.36 \\
\hline Takeover & 0.07 & 0.03 & -0.16 & 0.08 & 0.11 & 0.18 \\
\hline Return on capital & & -0.10 & -0.15 & -0.08 & -0.12 & -0.09 \\
\hline Chang in ret capital & & -0.08 & -0.06 & -0.06 & -0.09 & -0.07 \\
\hline Risk of unempl index & & 0.42 & 0.66 & 0.31 & 0.51 & 0.64 \\
\hline Prob of reempl index & & 0.05 & 0.20 & -0.04 & 0.11 & 0.20 \\
\hline Percent $w$ outcome $=1$ & 2.96 & 2.90 & 3.22 & 2.03 & 3.54 & 4.23 \\
\hline Observations & 524,270 & 489,368 & 232,684 & 388,592 & 349,757 & 208,311 \\
\hline
\end{tabular}


Table 8.

Estimated percentage point impacts of employment opportunities on temporary or permanent disability and nonparticipation. Women, full-time

Average marginal effects (AME)- Point estimates.

\begin{tabular}{|c|c|c|c|c|c|c|}
\hline & $\begin{array}{c} \\
\text { Omit profits } \\
\text { and labor } \\
\text { demand } \\
\text { indices } \\
\end{array}$ & $\begin{array}{c}\text { II } \\
\text { Firm size } \\
\text { stable last } \\
\text { two years }\end{array}$ & $\begin{array}{c}I I I \\
\text { More than } \\
50 \text { employ- } \\
\text { ees } \\
\end{array}$ & $\begin{array}{c}\text { IV } \\
\text { No welfare } \\
\text { benefits } \\
\text { prior two } \\
\text { years } \\
\end{array}$ & $\begin{array}{c}V \\
\text { Employed } \\
\text { in the same } \\
\text { firm prior } \\
\text { two years }\end{array}$ & $\begin{array}{c}\text { VI } \\
\text { Employed in } \\
\text { the same } \\
\text { firm prior } \\
\text { five years }\end{array}$ \\
\hline \multicolumn{7}{|c|}{ A) Temporary or permanent disability } \\
\hline 10-20 \% downsizing & 1.26 & 1.30 & 0.87 & 0.41 & 1.06 & 1.19 \\
\hline 20-35 \% downsizing & 1.25 & 1.25 & -0.27 & 0.79 & 1.25 & 1.29 \\
\hline 35-99\% downsizing & 1.02 & 0.71 & -0.34 & 0.56 & 0.66 & 1.21 \\
\hline Closure w bankruptcy & 5.15 & 4.19 & 2.44 & 4.91 & 4.91 & 6.43 \\
\hline Liquidation & 1.89 & 1.60 & -0.10 & 1.45 & 1.54 & 1.63 \\
\hline Takeover & 1.41 & 1.50 & 1.89 & 1.32 & 1.66 & 1.82 \\
\hline Return on capital & & -0.63 & -0.81 & -0.44 & -0.68 & -0.86 \\
\hline Chang in ret capital & & -0.29 & -0.50 & -0.39 & -0.52 & -0.40 \\
\hline Risk of unempl index & & 1.82 & 1.96 & 1.56 & 1.29 & 1.08 \\
\hline Prob of reempl index & & -0.39 & -0.34 & -0.65 & -0.51 & -0.82 \\
\hline Percent w outcome $=1$ & 18.81 & 18.74 & 19.81 & 13.4 & 19.00 & 18.97 \\
\hline \multicolumn{7}{|c|}{ B) Out of labor force } \\
\hline 10-20 \% downsizing & 1.65 & 1.49 & 2.05 & 1.25 & 1.58 & 1.79 \\
\hline 20-35 \% downsizing & 2.26 & 2.22 & 1.67 & 1.93 & 1.93 & 1.53 \\
\hline 35-99\% downsizing & 4.29 & 3.75 & 3.61 & 3.42 & 3.92 & 4.61 \\
\hline Closure w bankruptcy & 10.50 & 9.45 & 8.94 & 8.85 & 13.27 & 14.45 \\
\hline Liquidation & 4.89 & 4.45 & 3.12 & 4.34 & 5.22 & 5.88 \\
\hline Takeover & 0.93 & 1.02 & 0.87 & 0.93 & 1.38 & 1.35 \\
\hline Return on capital & & -0.43 & -0.90 & -0.32 & -0.65 & -0.79 \\
\hline Chang in ret capital & & -0.34 & -0.53 & -0.48 & -0.62 & -0.61 \\
\hline Risk of unempl index & & -0.16 & -0.74 & -0.24 & -0.69 & -1.12 \\
\hline Prob of reempl index & & -2.46 & -2.83 & -1.97 & -1.73 & -1.94 \\
\hline Percent w outcome $=1$ & 16.23 & 16.11 & 16.06 & 12.57 & 15.11 & 15.04 \\
\hline \multicolumn{7}{|c|}{ C) Permanent disability } \\
\hline 10-20 \% downsizing & 0.21 & 0.18 & 0.46 & -0.04 & 0.10 & -0.05 \\
\hline 20-35 \% downsizing & 0.45 & 0.40 & 0.20 & 0.28 & 0.56 & 0.65 \\
\hline 35-99\% downsizing & 0.79 & 0.62 & 0.65 & 0.63 & 1.09 & 1.38 \\
\hline Closure w bankruptcy & 1.44 & 1.36 & 1.87 & 1.66 & 2.37 & 3.44 \\
\hline Liquidation & 0.88 & 0.76 & 0.04 & 0.61 & 1.14 & 0.96 \\
\hline Takeover & 0.26 & 0.31 & 0.36 & 0.20 & 0.35 & 0.41 \\
\hline Return on capital & & -0.10 & -0.23 & -0.08 & -0.19 & -0.34 \\
\hline Chang in ret capital & & -0.10 & -0.10 & -0.04 & -0.06 & -0.03 \\
\hline Risk of unempl index & & 0.29 & 0.16 & 0.13 & 0.24 & 0.50 \\
\hline Prob of reempl index & & -0.26 & -0.29 & -0.14 & -0.23 & -0.25 \\
\hline Percent $w$ outcome $=1$ & 3.77 & 3.71 & 3.94 & 2.59 & 4.86 & 6.17 \\
\hline Observations & 174,194 & 162,547 & 73,063 & 119,858 & 108,315 & 61,320 \\
\hline
\end{tabular}


define our samples broadly and include workers with short tenure in the baseline sample. In the empirical literature, however, the common practice is to focus on high-seniority workers, typically for reasons of eliminating voluntary quits and firings for cause from the treatment group. ${ }^{14}$ In our application, limiting the sample to those with high firm attachment will entail looking at an older group of workers and also reducing contamination in the reference group. As evidence of the former, we note that the average age of the samples underlying column VI is 44.2 for men and 44.8 for women (compared to 39.4 and 38.7 in the baseline, as Table 2 showed). Moreover, in the high-seniority sample the four-year unemployment incidence rate in the reference group is reduced by almost one half when compared to the baseline, a strong indication of less contamination, while for workers in the treatment group unemployment incidence rates are similar regardless of sample restriction. ${ }^{15}$ Both of these factors will produce larger effect estimates. Importantly, the finding that contamination bias declines with seniority provides further justification for the sample condition of focusing on high-seniority workers used in many studies of worker displacement, beyond the concerns about heterogeneous effects and intent to treat cited in those studies.

Adjusting for contamination bias in the same way as we did for the baseline model, we find that among males with at least two years of seniority displacement raises the risk of permanent disability by 3.6 percentage points (138 percent). With the five-year

${ }^{14}$ A number of studies adopt the U.S. Bureau of Labor Statistics definition of displacement and limit samples to workers with at least three years of seniority (Fallick, 1996). See also the discussions of high vs. low tenure workers and the implications for measurement of displacement effects in Jacobson et al. (1993) and von Wachter et al. (2009).

${ }^{15}$ Four-year unemployment incidence rates in the reference group underlying column VI are 7.4 percent for men and 7.7 percent for women, compared to 12.4 and 13.1 percent in the baseline (see Table 3). In the treatment group (i.e., the bankruptcy bracket), unemployment incidence rates are 56.0 percent for men and 65.5 percent for women in the high-seniority sample, compared to 56.5 and 62.2 percent in the baseline sample. 
seniority restriction, the risk is estimated to go up by 4.3 percentage points (132 percent).

For females, the corresponding effects are 2.8 percentage points (68 percent) when we impose the two-year seniority restriction and 3.9 percentage points (73 percent) with the five-year restriction. For men, the fraction of new disability claims accounted for by displacement declines somewhat with tenure (from 28 percent for all workers to 23 percent for workers with at least five years of seniority), while for women the fraction remains stable at around 13 percent regardless of sample restriction on seniority. In conclusion, although point estimates vary somewhat across the different sample specifications for some of the outcome measures and for some of the downsizing indicators, their overall stability - particularly in relative terms - shows that the key findings reported in this paper are highly robust with respect to alternative sampling schemes.

\subsection{Effects on mortality and family dissolution}

Our finding that employment opportunities have a strong impact on subsequent disability benefit claims does not necessarily imply that the disability status results directly from unemployment. Previous evidence from Norway suggests that job loss adversely affects employees’ physical and mental health conditions (Rege et al., 2009) and also potentially triggers other traumatic events, such as family dissolution (Rege et al., 2007).

To check for possible health effects of job loss, we extend our samples and include workers who otherwise satisfy initial sample criteria, but who died during the sixyear outcome period. We next estimate the impacts of employment opportunities on mortality in exactly the same manner as we have estimated the impacts on other outcome measures. The results are reported in Table 9. Displacement appears to raise mortality for men. Adjusting the estimated bankruptcy effect for contamination bias caused by inclu- 
Table 9.

Estimated percentage point impacts of employment opportunities on mortality six years after base year.

\begin{tabular}{|c|c|c|c|c|}
\hline & \multicolumn{2}{|c|}{ Men } & \multicolumn{2}{|c|}{ Women } \\
\hline & $A M E$ & $R S E$ & $A M E$ & RSE \\
\hline No downsizing $(<10 \%)$ & Ref. & & Ref. & \\
\hline 10-20 \% downsizing & 0.11 & 0.05 & 0.13 & 0.07 \\
\hline 20-35 \% downsizing & 0.09 & 0.06 & 0.09 & 0.07 \\
\hline 35-99\% downsizing & 0.09 & 0.05 & 0.06 & 0.06 \\
\hline Closure with bankruptcy & 0.26 & 0.10 & 0.06 & 0.15 \\
\hline Liquidation & 0.08 & 0.08 & -0.10 & 0.08 \\
\hline Takeover & 0.10 & 0.05 & 0.01 & 0.06 \\
\hline Initial rate of return on capital ${ }^{\#}$ & 0.00 & 0.02 & 0.00 & 0.02 \\
\hline Change in return on capital $^{\#}$ & -0.05 & 0.02 & 0.01 & 0.02 \\
\hline Risk of unemployment ${ }^{\#}$ & 0.13 & 0.07 & -0.06 & 0.08 \\
\hline Probability of reemployment ${ }^{\#}$ & 0.02 & 0.05 & -0.04 & 0.07 \\
\hline Percent with outcome $=1$ & & & & \\
\hline Observations & & & & \\
\hline
\end{tabular}

${ }^{\#}$ Marginal effects are calculated as the effect of a one standard deviation change in the explanatory variable. See also notes to Table 5.

sion of displaced employees in the control group (non-downsizing firms), we find that displacement raises the six-year mortality rate for men by 0.33 percentage points (34 percent). This implies that around 10 percent of the deaths among male workers in our data can be attributed to job displacement. A general deterioration of local industry-specific risk of unemployment also tends to raise mortality among men. For women, we uncover no statistical evidence that displacement or unemployment risk raises mortality, although coefficient estimates of the downsizing variables (without closure) are similar in size to those for men. The latter is consistent with a large literature indicating that the uncertainty associated with organizational change adversely affects the health of retained employees; see, e.g., Ferrie (2001) and Røed and Fevang (2007), the latter for recent Norwegian evidence. 
Table 10.

Estimated percentage point impacts of employment opportunities on divorce four years after base year.

\begin{tabular}{|c|c|c|c|c|}
\hline & \multicolumn{2}{|c|}{ Men } & \multicolumn{2}{|c|}{ Women } \\
\hline & $A M E$ & $R S E$ & $A M E$ & RSE \\
\hline No downsizing $(<10 \%)$ & Ref. & & Ref. & \\
\hline 10-20 \% downsizing & -0.04 & 0.16 & -0.11 & 0.31 \\
\hline 20-35 \% downsizing & 0.33 & 0.18 & -0.17 & 0.31 \\
\hline 35-99\% downsizing & 0.49 & 0.15 & 0.81 & 0.28 \\
\hline Closure with bankruptcy & 1.13 & 0.34 & 0.18 & 0.69 \\
\hline Liquidation & 0.42 & 0.22 & 0.13 & 0.37 \\
\hline Takeover & -0.22 & 0.15 & -0.25 & 0.28 \\
\hline Initial rate of return on capital ${ }^{\#}$ & -0.16 & 0.05 & -0.04 & 0.10 \\
\hline Change in return on capital $^{\#}$ & -0.17 & 0.05 & -0.17 & 0.10 \\
\hline Risk of unemployment ${ }^{\#}$ & -0.08 & 0.22 & -0.77 & 0.38 \\
\hline Probability of reemployment ${ }^{\#}$ & -0.20 & 0.25 & -1.14 & 0.48 \\
\hline Percent with outcome $=1$ & & & & \\
\hline Observations & & & & \\
\hline
\end{tabular}

${ }^{\#}$ Marginal effects are calculated as the effect of a one standard deviation change in the explanatory variable. See also notes to Table 5.

As a final investigation of the diverse consequences of job loss, we next consider family dissolution as an endogenous outcome. The results from the exercise where divorce is the dependent variable, and where the sample is restricted to those married at the end of the base year, are presented in Table 10. Adjusted for contamination bias, the results suggest that displacement raises the divorce risk for men by 1.45 percentage points (28 percent), and that displacements account for roughly eight percent the family dissolutions among male workers in our data. There are no effects for women. Again, these findings may indicate an additional channel for causality from displacement to disability, at least for men, since it is probable that family dissolution will affect the risk of disability. Indeed, if we include an indicator variable for divorce during the (four-year) period in the baseline model outlined in Section 3.2, we find that family dissolution has a significant and positive effect on the disability propensity among men (but not among women); and 
that divorce raises the permanent disability probability of men by 0.5 percentage point (20 percent).

\subsection{Relation to previous evidence}

The effect of downsizing on disability pension utilization in Norway has previously been investigated by Rege et al. (2009). Based on a similar empirical approach to the one used here, they find that workers originally employed in plants that downsized by more than 60 percent between 1995 and 2000, were 24 percent more likely to utilize disability pensions in 2001 than comparable workers in non-downsizing plants. In the published article, the authors do not distinguish between large downsizings and complete closures. But they employ the distinction in a working-paper version of their study (Rege et al., 2005), reporting that workers originally employed in closing plants were less likely to enter disability than workers employed in downsizing plants. Our own findings suggest otherwise, and further imply that the adverse effects of displacement in truth are much larger than indicated by the results in Rege et al. (2005). We suspect that the discrepancy between empirical findings results from differences in the way closures are identified. As stated above, without direct information on the reason for closure it is likely that many of the presumed closures in employer-employee data actually are reorganizations, e.g., in the form of demergers and takeovers. In our data, as many as 60 percent of the jobs in closing firms turn out to be acquisitions by other companies; see Table 2. This problem clearly also imposes measurement error in the downsizing indicators (for example related to outsourcing), although to a lesser extent. Although the Rege et al. studies take steps to eliminate false downsizings from their data (for example, by recoding cases where large groups of workers move together to a new company), some misclassifications are likely 
to remain. First, there will inevitably be some "false" mass layoffs generated by organizational change that splits employees into multiple companies. Second, there will be some genuine mass layoffs that erroneously are classified as "false" because the displaced employees succeed in establishing a new company in response to their displacement. To examine the empirical relevance of such measurement error, we have replicated the downsizing indicators used by Rege et al. (2009), as described in their footnote 25 (page 767). Using the alternative measure, our estimated effect of a large downsizing event on disability enrollment (estimated jointly for men and women) becomes virtually identical to the estimate of Rege et al. (2009): They report an estimated odds-ratio associated with 60-100 percent downsizing of 1.30 ; our own corresponding estimate is 1.31 . We have also partly replicated the downsizing indicators used by Rege et al. (2005), where closure is defined as a distinct event. ${ }^{16}$ Consistent with their results, we find that both downsizings and closures raise the permanent disability propensity by around 25-30 percent, and that a closure does not entail a larger effect than a moderate downsizing.

In their study of short and long-term consequences of displacement, Huttunen et al. (2010) also examine the impact of displacement on subsequent non-participation among male workers, reporting that the probability of being outside the labor force is 3.4 percentage points higher seven years after displacement than for otherwise similar, but non-displaced, workers. The study defines displaced individuals as workers who separate from plants that close down or reduce employment by 30 percent or more. Even though they restrict the sample to high-attachment workers, this strategy entails two potential

${ }^{16}$ In this exercise, closure is defined as a downsizing between 95 and 100 percent. Even though we replicate their grouping of downsizing/closure events, we have not attempted to define these events exactly the same way. While Rege et al. (2005) define downsizing/closure as annual events, both Rege et al. (2009) and we define the variables in terms of change in firm size over a four-year period. 
sources of bias. Again, register-based downsizing indicators will invariably capture some false downsizings, related to outsourcing, demergers, and other forms of organizational change. Second, some separations are voluntary, even when they occur in downsizing firms. In fact, Huttunen et al. (2010) point out themselves that their strategy for identifying displacement will involve some misclassifications and that the estimated effects may be imparted by downward bias. Our results, showing much larger effects of displacement on labor market withdrawal, suggest that this indeed is the case.

Rege et al. (2009) also investigate the impact of downsizing on mortality, and report that workers older than 40 who were originally employed in plants that downsized by more than 60 percent during 1995-2000 were 14 percent more likely to have died by 2001 than comparable workers in non-downsized plants. Our results indicate that the true impact of displacement may be substantially higher, although large standard errors prevent us from drawing firm conclusions in this regard. ${ }^{17}$ Finally, Rege et al. (2007) examine the impact of plant closure on family dissolution, and find that marriages of husbands originally employed in plants that closed down between 1995 and 2000 were 11 percent more likely to be dissolved by 2003 than comparable marriages of husbands in stable plants. Once again, our results suggest that the true effect is larger.

We infer from these exercises that downsizing and closure indicators computed solely from employment registers, and using conventional approaches for eliminating noisy observations, contain substantial measurement error that renders biased estimators.

\footnotetext{
17 The causal link between displacement and mortality risk has also been studied in other countries. For example, Eliason and Storrie (2009b) and Sullivan and von Wacther (2009) report mortality effects among displaced male workers in Sweden and Pennsylvania, respectively, that are even larger than those of the present study. Martikainen et al. (2007) uncover an association between unemployment and mortality risk in Finland, but argue that there is no excess mortality among displaced workers.
} 
In the present paper, we exploit information on recorded bankruptcies to construct a more reliable indicator for exogenous displacement. With this indicator, we find that the adverse impacts of displacement - in terms of higher subsequent disability and nonparticipation risks - are much larger than what has been previously recognized in the literature.

\section{Concluding remarks}

We have shown in this paper that negative shifts in employment opportunities explain significant shares of non-participation and disability insurance dependency in Norway. The causal relationship between employment opportunities and disability is particularly strong for male workers.

Our findings suggest that the process of reallocating redundant workers from old to new employers is far from seamless, and that many displaced workers permanently change status from supporting the welfare state to becoming supported by it. Significant human capital resources are squandered in this process.

Even though our empirical analysis also indicates that job displacement have adverse health effects, the strong causal link between employment opportunity and disability enrollment leads us to conclude that there is a considerable grey area between unemployment and disability and that a substantial share of the Norwegian disability problem really is an unemployment problem in disguise. The unemployment and disability insurance programs are in many cases close substitutes. 


\section{References}

Autor, D., and Duggan, M.G. (2003) The Rise in the Disability Rolls and the Decline in Unemployment. The Quarterly Journal of Economics, Vol. 118, 157-205.

Bartus, T. (2005) Estimation of Marginal Effects Using Margeff. The Stata Journal, Vol. 5, No. 3, 309-329.

Black, D., Daniel, K., and Sanders, S. (2002) The Impact of Economic Conditions on Participation in Disability Programs: Evidence from the Coal Boom and Bust. American Economic Review, Vol. 92, 27-50.

Bound, J., and Burkhauser, R. V. (1999) Economic Analysis of Transfer Programs for People with Disabilities. In O. Ashenfelter and D. Card (eds.): Handbook of Labor Economics, Vol. 3C, Elsevier.

Bratberg, E. (1999) Disability Retirement in a Welfare State. Scandinavian Journal of Economics, Vol. 101, No. 1, 97-114.

Bratsberg, B., Fevang, E., and Røed, K. (2010a) The Rise in Disability. In progress.

Bratsberg, B., Raaum, O., and Røed, K. (2010b) When Minority Labor Migrants Meet the Welfare State. Journal of Labor Economics, forthcoming.

Dahl, S.-Å., Anti Nilsen, Ø., and Vaage, K. (2000) Work or Retirement? Exit Routes for Norwegian Elderly. Applied Economics, Vol. 32, No. 14, 1865-1876.

Eliason, M., and Storrie, D. (2009a) Job Loss is Bad for Your Health - Swedish Evidence on Cause-Specific Hospitalization Following Involuntary Job Loss. Social Science \& Medicine, Vol. 68, No. 8, 1396-1406.

Eliason, M., and Storrie, D. (2009b) Does Job Loss Shorten Life? Journal of Human Resources, Vol. 44, No. 2, 277-302.

Fallick, B. (1996) A Review of the Recent Empirical Literature on Displaced Workers. Industrial and Labor Relations Review, Vol. 50, No. 1, 5-16.

Ferrie, J.E. (2001) Is Job Insecurity Harmful to Health? Journal of the Royal Society of Medicine, Vol. 94, 71-76.

Fevang, E., and Røed, K. (2006) Veien til uføretrygd i Norge. Rapport 10/2006. Stiftelsen Frischsenteret for samfunnsøkonomisk forskning. (www.frisch.uio.no/pdf/rapp06_10.pdf)

Gibbons, R., and Katz, L. (1991) Layoffs and Lemons. Journal of Labor Economics, Vol. 9, No. 4, 351-380. 
Hallock, K.F. (2009) Job Loss and the Fraying of the Implicit Employment Contract. Journal of Economic Perspectives, Vol. 23, No. 4, 69-93.

Hamermesh, D. (1987) The Costs of Worker Displacement. Quarterly Journal of Economics, Vol. 102, No. 1, 51-76.

Heckman, J. J., and Robb, R. (1985) Alternative methods for evaluating the impact of interventions: An overview. Journal of Econometrics, Vol. 30, 239-267.

Henningsen, M., and Hægeland, T. (2008) Downsizing as a sorting device. Are lowproductive workers more likely to leave downsizing firms? Discussion Paper 543, Statistics Norway.

Huttunen, K., Møen, J., and Salvanes, K.G. (2010) How Destructive is Creative Destruction? Effects of Job Loss on Mobility, Withdrawal and Income. Journal of the European Economic Association, forthcoming.

Jacobson, L.S., Lalonde, J.T., and Sullivan, D.G. (1993) Earnings Losses of Displaced Workers. American Economic Review, Vol. 83, No. 4, 685-709.

Kasl, S., and Jones, B. (2002) The Impact of Job Loss and Retirement on Health. In B.A. Kawachi (ed.): Social Epidemiology, Oxford University Press.

Kletzer, L.G. (1998.) Job Displacement. Journal of Economic Perspectives, Vol. 12, No. 1, 115-136.

Kuhn, P.J., ed. (2002). Losing Work, Moving On. International Perspectives on Worker Displacement. W.E. Upjohn Institute for Employment Research, Kalamazoo, Michigan.

Martikainen, P., Maki, N., and Jantti, M. (2007) The effects of unemployment on mortality following workplace downsizing and workplace closure: A register-based follow-up study of Finnish men and women during economic boom and recession. American Journal of Epidemiology, Vol. 165, No. 9, 1070-1075.

Moulton, B.R. (1986) Random Group Effects and the Precision of Regression Estimates. Journal of Econometrics, Vol. 32, No. 3, 385-397

Neal, D. (1995) Industry-Specific Human Capital: Evidence from Displaced Workers. Journal of Labor Economics, Vol. 13, No. 4, 653-677.

OECD (2003) Transforming Disability into Ability. Policies to Promote Work and Income Security for Disabled People. OECD, Paris.

OECD (2008) OECD Employment Outlook 2008, OECD, Paris.

OECD (2009) Sickness, Disability and Work - Keeping on Track in the Economic Downturn. Background Paper (www.oecd.org/dataoecd/42/15/42699911.pdf) 
Rege, M., Telle, K., and Votruba, M. (2005) The Effect of Plant Downsizing on Disability Pension Utilization. Discussion Papers No. 435, Statistics Norway, Research Department.

Rege, M., Telle, K., and Votruba, M. (2007) Plant Closure and Marital Dissolution, Discussion Papers No. 514, Research Department, Statistics Norway

Rege, M., Telle, K., and Votruba, M. (2009) The Effect of Plant Downsizing on Disability Pension Utilization. Journal of the European Economic Association, Vol. 7, No. 5, 754-785.

Ruhm, C.J. (1991) Are Workers Permanently Scarred by Job Displacements? The American Economic Review, Vol. 81, No. 1, 319-324.

Røed, K., and Fevang, E. (2007) Organizational Change, Absenteeism and Welfare Dependency. Journal of Human Resources, Vol. 42, No. 1, 156-193.

Salvanes, K.G. (1997) Market Rigidities and Labour Market Flexibility: An International Comparison. The Scandinavian Journal of Economics, Vol. 99, No. 2, pp. 315-333.

Sullivan, D., and von Wachter, T. (2009) Job Displacement and Mortality: An Analysis Using Administrative Data. Quarterly Journal of Economics, Vol. 124, No. 3, 1265-1306.

von Wachter, T., Song, J., and Manchester, J. (2009) Long-Term Earnings Losses Due to Job Displacement during the 1982 Recession: An Analysis Using Longitudinal Administrative Data from 1974 to 2004. Mimeo, Columbia University.

\section{Appendix}

\section{Detailed logit regression results}

\begin{tabular}{|c|c|c|c|c|c|c|}
\hline \multirow[b]{2}{*}{$\begin{array}{l}\text { Dependent } \\
\text { variable: }\end{array}$} & \multicolumn{3}{|c|}{ Men } & \multicolumn{3}{|c|}{ Women } \\
\hline & $\begin{array}{l}\text { Disability } \\
\text { (4 yrs) }\end{array}$ & $\begin{array}{c}\text { Out of labor } \\
\text { force } \\
\text { (4 yrs) }\end{array}$ & $\begin{array}{c}\text { Permanent } \\
\text { disability } \\
\text { (6 yrs) }\end{array}$ & $\begin{array}{c}\text { Disability } \\
\text { (4 yrs) }\end{array}$ & $\begin{array}{c}\text { Out of labor } \\
\text { force } \\
\text { (4 yrs) }\end{array}$ & $\begin{array}{c}\text { Permanent } \\
\text { disability } \\
\text { (6 yrs) }\end{array}$ \\
\hline \multirow{2}{*}{ Age 20 in base yr } & -0.763 & -0.606 & -3.640 & -0.287 & 0.609 & -3.047 \\
\hline & $(0.075)$ & $(0.156)$ & $(0.346)$ & $(0.090)$ & $(0.092)$ & $(0.445)$ \\
\hline \multirow[t]{2}{*}{ Age 21} & -0.390 & -0.377 & -3.198 & -0.007 & 0.728 & -3.932 \\
\hline & $(0.071)$ & $(0.157)$ & (0.333) & $(0.087)$ & $(0.091)$ & (0.729) \\
\hline \multirow[t]{2}{*}{ Age 22} & -0.317 & -0.449 & -2.630 & 0.163 & 0.697 & -2.308 \\
\hline & $(0.071)$ & $(0.155)$ & $(0.276)$ & $(0.086)$ & $(0.092)$ & (0.373) \\
\hline \multirow[t]{2}{*}{ Age 23} & -0.194 & -0.438 & -2.386 & 0.223 & 0.574 & -2.203 \\
\hline & $(0.068)$ & $(0.151)$ & $(0.260)$ & (0.083) & $(0.091)$ & (0.358) \\
\hline \multirow[t]{2}{*}{ Age 24} & -0.198 & -0.456 & -2.581 & 0.192 & 0.482 & -2.473 \\
\hline & $(0.067)$ & (0.143) & $(0.274)$ & $(0.081)$ & $(0.090)$ & (0.387) \\
\hline \multirow[t]{2}{*}{ Age 25} & -0.176 & -0.414 & -2.272 & 0.153 & 0.409 & -1.974 \\
\hline & $(0.064)$ & (0.136) & $(0.245)$ & $(0.078)$ & $(0.086)$ & $(0.312)$ \\
\hline \multirow[t]{2}{*}{ Age 26} & -0.209 & -0.492 & -2.532 & 0.199 & 0.364 & -2.155 \\
\hline & $(0.061)$ & $(0.130)$ & (0.265) & $(0.073)$ & $(0.082)$ & $(0.324)$ \\
\hline
\end{tabular}




\begin{tabular}{|c|c|c|c|c|c|c|}
\hline Age 27 & $\begin{array}{c}-0.142 \\
(0.058)\end{array}$ & $\begin{array}{c}-0.424 \\
(0.125)\end{array}$ & $\begin{array}{l}-1.758 \\
(0.202)\end{array}$ & $\begin{array}{c}0.179 \\
(0.070)\end{array}$ & $\begin{array}{c}0.361 \\
(0.079)\end{array}$ & $\begin{array}{l}-1.487 \\
(0.251)\end{array}$ \\
\hline Age 28 & $\begin{array}{c}-0.151 \\
(0.055)\end{array}$ & $\begin{array}{l}-0.454 \\
(0.116)\end{array}$ & $\begin{array}{l}-1.616 \\
(0.187)\end{array}$ & $\begin{array}{c}0.276 \\
(0.067)\end{array}$ & $\begin{array}{c}0.366 \\
(0.075)\end{array}$ & $\begin{array}{l}-1.525 \\
(0.254)\end{array}$ \\
\hline Age 29 & $\begin{array}{c}-0.119 \\
(0.052)\end{array}$ & $\begin{array}{l}-0.367 \\
(0.107)\end{array}$ & $\begin{array}{l}-1.342 \\
(0.175)\end{array}$ & $\begin{array}{c}0.258 \\
(0.064)\end{array}$ & $\begin{array}{c}0.420 \\
(0.073)\end{array}$ & $\begin{array}{l}-1.169 \\
(0.222)\end{array}$ \\
\hline Age 30 & $\begin{array}{l}-0.181 \\
(0.051)\end{array}$ & $\begin{array}{l}-0.402 \\
(0.097)\end{array}$ & $\begin{array}{l}-1.327 \\
(0.174)\end{array}$ & $\begin{array}{c}0.230 \\
(0.062)\end{array}$ & $\begin{array}{c}0.330 \\
(0.071)\end{array}$ & $\begin{array}{l}-1.302 \\
(0.227)\end{array}$ \\
\hline Age 31 & $\begin{array}{l}-0.105 \\
(0.048)\end{array}$ & $\begin{array}{l}-0.334 \\
(0.093)\end{array}$ & $\begin{array}{l}-1.206 \\
(0.168)\end{array}$ & $\begin{array}{c}0.254 \\
(0.060)\end{array}$ & $\begin{array}{c}0.295 \\
(0.069)\end{array}$ & $\begin{array}{c}-1.073 \\
(0.215)\end{array}$ \\
\hline Age 32 & $\begin{array}{c}-0.160 \\
(0.047)\end{array}$ & $\begin{array}{c}-0.312 \\
(0.086)\end{array}$ & $\begin{array}{l}-0.966 \\
(0.161)\end{array}$ & $\begin{array}{c}0.217 \\
(0.059)\end{array}$ & $\begin{array}{c}0.334 \\
(0.067)\end{array}$ & $\begin{array}{c}-0.950 \\
(0.203)\end{array}$ \\
\hline Age 33 & $\begin{array}{l}-0.129 \\
(0.045)\end{array}$ & $\begin{array}{l}-0.306 \\
(0.074)\end{array}$ & $\begin{array}{l}-0.946 \\
(0.157)\end{array}$ & $\begin{array}{c}0.180 \\
(0.058)\end{array}$ & $\begin{array}{c}0.235 \\
(0.066)\end{array}$ & $\begin{array}{l}-0.586 \\
(0.182)\end{array}$ \\
\hline Age 34 & $\begin{array}{l}-0.137 \\
(0.044)\end{array}$ & $\begin{array}{l}-0.248 \\
(0.066)\end{array}$ & $\begin{array}{l}-0.713 \\
(0.143)\end{array}$ & $\begin{array}{c}0.164 \\
(0.058)\end{array}$ & $\begin{array}{c}0.257 \\
(0.067)\end{array}$ & $\begin{array}{l}-0.445 \\
(0.179)\end{array}$ \\
\hline Age 35 & $\begin{array}{l}-0.095 \\
(0.042)\end{array}$ & $\begin{array}{l}-0.197 \\
(0.060)\end{array}$ & $\begin{array}{l}-0.576 \\
(0.139)\end{array}$ & $\begin{array}{c}0.171 \\
(0.058)\end{array}$ & $\begin{array}{c}0.206 \\
(0.066)\end{array}$ & $\begin{array}{l}-0.149 \\
(0.165)\end{array}$ \\
\hline Age 36 & $\begin{array}{l}-0.083 \\
(0.042)\end{array}$ & $\begin{array}{l}-0.169 \\
(0.060)\end{array}$ & $\begin{array}{l}-0.363 \\
(0.131)\end{array}$ & $\begin{array}{c}0.164 \\
(0.057)\end{array}$ & $\begin{array}{c}0.187 \\
(0.067)\end{array}$ & $\begin{array}{l}-0.462 \\
(0.182)\end{array}$ \\
\hline Age 37 & $\begin{array}{c}0.020 \\
(0.041)\end{array}$ & $\begin{array}{l}-0.076 \\
(0.055)\end{array}$ & $\begin{array}{l}-0.272 \\
(0.128)\end{array}$ & $\begin{array}{c}0.120 \\
(0.058)\end{array}$ & $\begin{array}{c}0.169 \\
(0.067)\end{array}$ & $\begin{array}{l}-0.143 \\
(0.165)\end{array}$ \\
\hline Age 38 & $\begin{array}{l}-0.075 \\
(0.040)\end{array}$ & $\begin{array}{l}-0.062 \\
(0.051)\end{array}$ & $\begin{array}{l}-0.174 \\
(0.126)\end{array}$ & $\begin{array}{c}0.144 \\
(0.058)\end{array}$ & $\begin{array}{c}0.144 \\
(0.068)\end{array}$ & $\begin{array}{l}-0.150 \\
(0.166)\end{array}$ \\
\hline Age 39 & $\begin{array}{c}0.014 \\
(0.038)\end{array}$ & $\begin{array}{c}0.027 \\
(0.048)\end{array}$ & $\begin{array}{c}-0.162 \\
(0.121)\end{array}$ & $\begin{array}{c}0.101 \\
(0.057)\end{array}$ & $\begin{array}{c}0.069 \\
(0.068)\end{array}$ & $\begin{array}{c}-0.043 \\
(0.163)\end{array}$ \\
\hline Age 40 & & & & & & \\
\hline Age 41 & $\begin{array}{c}0.041 \\
(0.039)\end{array}$ & $\begin{array}{c}0.061 \\
(0.049)\end{array}$ & $\begin{array}{c}0.232 \\
(0.111)\end{array}$ & $\begin{array}{c}0.095 \\
(0.059)\end{array}$ & $\begin{array}{c}0.092 \\
(0.070)\end{array}$ & $\begin{array}{c}0.265 \\
(0.149)\end{array}$ \\
\hline Age 42 & $\begin{array}{c}0.066 \\
(0.039)\end{array}$ & $\begin{array}{c}0.124 \\
(0.053)\end{array}$ & $\begin{array}{c}0.219 \\
(0.111)\end{array}$ & $\begin{array}{c}0.119 \\
(0.059)\end{array}$ & $\begin{array}{c}0.135 \\
(0.070)\end{array}$ & $\begin{array}{c}0.338 \\
(0.148)\end{array}$ \\
\hline Age 43 & $\begin{array}{c}0.075 \\
(0.041)\end{array}$ & $\begin{array}{c}0.188 \\
(0.055)\end{array}$ & $\begin{array}{c}0.374 \\
(0.109)\end{array}$ & $\begin{array}{c}0.177 \\
(0.058)\end{array}$ & $\begin{array}{c}0.112 \\
(0.070)\end{array}$ & $\begin{array}{c}0.477 \\
(0.144)\end{array}$ \\
\hline Age 44 & $\begin{array}{c}0.098 \\
(0.042)\end{array}$ & $\begin{array}{c}0.201 \\
(0.057)\end{array}$ & $\begin{array}{c}0.390 \\
(0.115)\end{array}$ & $\begin{array}{c}0.140 \\
(0.059)\end{array}$ & $\begin{array}{c}0.040 \\
(0.070)\end{array}$ & $\begin{array}{c}0.461 \\
(0.144)\end{array}$ \\
\hline Age 45 & $\begin{array}{c}0.076 \\
(0.043)\end{array}$ & $\begin{array}{c}0.202 \\
(0.061)\end{array}$ & $\begin{array}{c}0.525 \\
(0.110)\end{array}$ & $\begin{array}{c}0.293 \\
(0.059)\end{array}$ & $\begin{array}{c}0.257 \\
(0.069)\end{array}$ & $\begin{array}{c}0.698 \\
(0.138)\end{array}$ \\
\hline Age 46 & $\begin{array}{c}0.170 \\
(0.044)\end{array}$ & $\begin{array}{c}0.295 \\
(0.065)\end{array}$ & $\begin{array}{c}0.688 \\
(0.109)\end{array}$ & $\begin{array}{c}0.278 \\
(0.061)\end{array}$ & $\begin{array}{c}0.204 \\
(0.071)\end{array}$ & $\begin{array}{c}0.669 \\
(0.140)\end{array}$ \\
\hline Age 47 & $\begin{array}{c}0.188 \\
(0.045)\end{array}$ & $\begin{array}{c}0.330 \\
(0.064)\end{array}$ & $\begin{array}{c}0.887 \\
(0.107)\end{array}$ & $\begin{array}{c}0.337 \\
(0.061)\end{array}$ & $\begin{array}{c}0.239 \\
(0.072)\end{array}$ & $\begin{array}{c}0.928 \\
(0.137)\end{array}$ \\
\hline Age 48 & $\begin{array}{c}0.235 \\
(0.046)\end{array}$ & $\begin{array}{c}0.356 \\
(0.063)\end{array}$ & $\begin{array}{l}1.011 \\
(0.106)\end{array}$ & $\begin{array}{c}0.380 \\
(0.063)\end{array}$ & $\begin{array}{c}0.204 \\
(0.073)\end{array}$ & $\begin{array}{c}0.862 \\
(0.140)\end{array}$ \\
\hline Age 49 & $\begin{array}{c}0.257 \\
(0.046)\end{array}$ & $\begin{array}{c}0.467 \\
(0.066)\end{array}$ & $\begin{array}{c}1.186 \\
(0.106)\end{array}$ & $\begin{array}{c}0.446 \\
(0.062)\end{array}$ & $\begin{array}{c}0.405 \\
(0.073)\end{array}$ & $\begin{array}{c}1.047 \\
(0.138)\end{array}$ \\
\hline Age 50 & $\begin{array}{c}0.270 \\
(0.048)\end{array}$ & $\begin{array}{c}0.436 \\
(0.068)\end{array}$ & $\begin{array}{l}1.176 \\
(0.106)\end{array}$ & $\begin{array}{c}0.456 \\
(0.064)\end{array}$ & $\begin{array}{c}0.364 \\
(0.075)\end{array}$ & $\begin{array}{c}1.060 \\
(0.138)\end{array}$ \\
\hline Age 51 & $\begin{array}{c}0.353 \\
(0.048)\end{array}$ & $\begin{array}{c}0.487 \\
(0.067)\end{array}$ & $\begin{array}{c}1.392 \\
(0.106)\end{array}$ & $\begin{array}{c}0.443 \\
(0.067)\end{array}$ & $\begin{array}{c}0.370 \\
(0.076)\end{array}$ & $\begin{array}{c}1.257 \\
(0.138)\end{array}$ \\
\hline Age 52 & $\begin{array}{c}0.407 \\
(0.049)\end{array}$ & $\begin{array}{c}0.559 \\
(0.066)\end{array}$ & $\begin{array}{l}1.553 \\
(0.107)\end{array}$ & $\begin{array}{c}0.479 \\
(0.067)\end{array}$ & $\begin{array}{c}0.458 \\
(0.076)\end{array}$ & $\begin{array}{c}1.412 \\
(0.140)\end{array}$ \\
\hline Age 53 & $\begin{array}{c}0.463 \\
(0.051)\end{array}$ & $\begin{array}{c}0.617 \\
(0.069)\end{array}$ & $\begin{array}{l}1.793 \\
(0.108)\end{array}$ & $\begin{array}{c}0.489 \\
(0.070)\end{array}$ & $\begin{array}{c}0.409 \\
(0.079)\end{array}$ & $\begin{array}{c}1.543 \\
(0.143)\end{array}$ \\
\hline Age 54 & $\begin{array}{c}0.479 \\
(0.054)\end{array}$ & $\begin{array}{c}0.649 \\
(0.071)\end{array}$ & $\begin{array}{c}1.967 \\
(0.110)\end{array}$ & $\begin{array}{c}0.478 \\
(0.073)\end{array}$ & $\begin{array}{c}0.377 \\
(0.082)\end{array}$ & $\begin{array}{c}1.514 \\
(0.144)\end{array}$ \\
\hline
\end{tabular}




\begin{tabular}{|c|c|c|c|c|c|c|}
\hline Age 55 & $\begin{array}{c}0.579 \\
(0.053)\end{array}$ & $\begin{array}{c}0.758 \\
(0.069)\end{array}$ & $\begin{array}{l}2.167 \\
(0.109)\end{array}$ & $\begin{array}{c}0.599 \\
(0.072)\end{array}$ & $\begin{array}{c}0.628 \\
(0.081)\end{array}$ & $\begin{array}{c}1.737 \\
(0.144)\end{array}$ \\
\hline Age 56 & 0.633 & 0.844 & 2.299 & 0.678 & 0.664 & 2.003 \\
\hline & $(0.055)$ & $(0.071)$ & $(0.111)$ & $(0.076)$ & $(0.085)$ & $(0.145)$ \\
\hline Age 57 & 0.767 & 0.974 & 2.570 & 0.617 & 0.590 & 2.073 \\
\hline & $(0.059)$ & $(0.074)$ & $(0.115)$ & $(0.083)$ & $(0.090)$ & $(0.152)$ \\
\hline Age 58 & 0.793 & 1.148 & 2.658 & 0.747 & 0.704 & 2.184 \\
\hline & $(0.064)$ & $(0.079)$ & $(0.121)$ & $(0.089)$ & $(0.098)$ & $(0.163)$ \\
\hline Age 59 & 1.103 & 0.936 & 3.185 & 0.921 & 0.508 & 2.422 \\
\hline & $(0.072)$ & $(0.092)$ & $(0.127)$ & $(0.100)$ & $(0.111)$ & $(0.175)$ \\
\hline Age 60 & 1.048 & 1.556 & 3.120 & 0.900 & 0.968 & 2.312 \\
\hline & $(0.088)$ & $(0.104)$ & $(0.148)$ & $(0.121)$ & $(0.125)$ & $(0.204)$ \\
\hline Age 61 & 1.037 & 1.728 & 3.182 & 0.956 & 1.133 & 2.354 \\
\hline & $(0.102)$ & $(0.119)$ & $(0.169)$ & $(0.141)$ & $(0.146)$ & $(0.235)$ \\
\hline Age 62 & 0.933 & 2.108 & 3.058 & 0.879 & 1.457 & 2.314 \\
\hline & $(0.111)$ & $(0.126)$ & $(0.181)$ & $(0.150)$ & $(0.156)$ & $(0.249)$ \\
\hline Age 63 & 1.039 & 2.217 & 2.952 & 1.047 & 1.531 & 2.249 \\
\hline & $(0.116)$ & $(0.132)$ & $(0.191)$ & $(0.155)$ & $(0.162)$ & $(0.265)$ \\
\hline Single (ref) & & & & & & \\
\hline Married & -0.047 & -0.273 & -0.101 & -0.037 & -0.003 & -0.003 \\
\hline & $(0.015)$ & $(0.018)$ & $(0.031)$ & $(0.022)$ & $(0.024)$ & $(0.053)$ \\
\hline Divorced & 0.257 & 0.108 & 0.118 & 0.295 & 0.174 & 0.186 \\
\hline & $(0.020)$ & $(0.023)$ & $(0.038)$ & $(0.025)$ & $(0.029)$ & $(0.057)$ \\
\hline Widow(er) & 0.019 & -0.110 & -0.097 & 0.133 & -0.034 & 0.051 \\
\hline & $(0.057)$ & $(0.061)$ & $(0.080)$ & $(0.053)$ & $(0.058)$ & $(0.084)$ \\
\hline Spouse & -0.013 & 0.184 & -0.033 & 0.010 & 0.066 & -0.215 \\
\hline home maker & $(0.030)$ & $(0.033)$ & $(0.039)$ & $(0.087)$ & $(0.099)$ & $(0.129)$ \\
\hline Spouse home* & -0.072 & -0.110 & 0.012 & -0.141 & 0.325 & -0.079 \\
\hline 1-2 children & $(0.041)$ & $(0.047)$ & $(0.081)$ & $(0.152)$ & $(0.141)$ & $(0.388)$ \\
\hline Spouse home* & -0.104 & -0.179 & 0.163 & 0.263 & -0.066 & 1.076 \\
\hline $3+$ children & $(0.050)$ & $(0.058)$ & $(0.122)$ & $(0.280)$ & $(0.316)$ & $(0.560)$ \\
\hline No children (ref) & & & & & & \\
\hline 1-2 children & 0.073 & -0.033 & -0.239 & 0.180 & 0.147 & -0.301 \\
\hline & $(0.013)$ & $(0.015)$ & $(0.028)$ & $(0.019)$ & $(0.021)$ & $(0.046)$ \\
\hline $3+$ children & 0.147 & 0.062 & -0.353 & 0.256 & 0.233 & -0.312 \\
\hline & $(0.022)$ & $(0.027)$ & $(0.061)$ & $(0.037)$ & $(0.040)$ & $(0.111)$ \\
\hline Low educ* & -0.031 & -0.155 & 0.134 & -0.015 & 0.019 & 0.012 \\
\hline primary industry & $(0.081)$ & $(0.081)$ & $(0.109)$ & $(0.127)$ & $(0.126)$ & $(0.178)$ \\
\hline $\begin{array}{l}\text { Low educ* } \\
\text { manufact (ref) }\end{array}$ & & & & & & \\
\hline Low educ* & -0.152 & -0.255 & 0.044 & -0.050 & -0.305 & -0.006 \\
\hline retail & $(0.039)$ & $(0.047)$ & $(0.065)$ & $(0.046)$ & $(0.051)$ & $(0.083)$ \\
\hline Low educ* & -0.165 & -0.122 & -0.100 & 0.052 & -0.169 & 0.114 \\
\hline hotel, rest & $(0.040)$ & $(0.045)$ & $(0.083)$ & $(0.036)$ & $(0.041)$ & $(0.064)$ \\
\hline Low educ* & 0.184 & -0.017 & 0.239 & -0.052 & -0.279 & -0.117 \\
\hline transport & $(0.042)$ & $(0.056)$ & $(0.070)$ & $(0.065)$ & $(0.070)$ & $(0.107)$ \\
\hline Low educ* & -0.177 & -0.088 & 0.035 & -0.113 & -0.262 & -0.170 \\
\hline finance & $(0.041)$ & $(0.057)$ & $(0.071)$ & $(0.042)$ & $(0.047)$ & $(0.076)$ \\
\hline Low educ* & -0.280 & -0.122 & -0.150 & -0.228 & -0.225 & -0.269 \\
\hline education & $(0.209)$ & $(0.221)$ & $(0.313)$ & $(0.153)$ & $(0.168)$ & $(0.273)$ \\
\hline Low educ* & 0.472 & 0.028 & 0.714 & 0.315 & -0.229 & 0.301 \\
\hline health service & $(0.073)$ & $(0.083)$ & $(0.109)$ & $(0.065)$ & $(0.073)$ & $(0.120)$ \\
\hline Low educ* & -0.054 & -0.179 & 0.158 & 0.120 & -0.261 & 0.059 \\
\hline other industry & $(0.061)$ & $(0.071)$ & $(0.107)$ & $(0.060)$ & $(0.070)$ & $(0.107)$ \\
\hline
\end{tabular}




\begin{tabular}{|c|c|c|c|c|c|c|}
\hline $\begin{array}{l}\text { Medium educ* } \\
\text { primary industry }\end{array}$ & $\begin{array}{l}-0.483 \\
(0.102)\end{array}$ & $\begin{array}{l}-0.467 \\
(0.113)\end{array}$ & $\begin{array}{l}-0.893 \\
(0.325)\end{array}$ & $\begin{array}{l}-0.407 \\
(0.165)\end{array}$ & $\begin{array}{l}-0.519 \\
(0.159)\end{array}$ & $\begin{array}{l}-1.985 \\
(1.017)\end{array}$ \\
\hline $\begin{array}{l}\text { Medium educ* } \\
\text { manufacturing }\end{array}$ & $\begin{array}{l}-0.192 \\
(0.019)\end{array}$ & $\begin{array}{l}-0.153 \\
(0.023)\end{array}$ & $\begin{array}{l}-0.202 \\
(0.033)\end{array}$ & $\begin{array}{l}-0.429 \\
(0.033)\end{array}$ & $\begin{array}{l}-0.295 \\
(0.035)\end{array}$ & $\begin{array}{l}-0.485 \\
(0.076)\end{array}$ \\
\hline $\begin{array}{l}\text { Medium educ* } \\
\text { retail }\end{array}$ & $\begin{array}{l}-0.470 \\
(0.043)\end{array}$ & $\begin{array}{l}-0.410 \\
(0.053)\end{array}$ & $\begin{array}{l}-0.289 \\
(0.079)\end{array}$ & $\begin{array}{l}-0.400 \\
(0.051)\end{array}$ & $\begin{array}{l}-0.398 \\
(0.055)\end{array}$ & $\begin{array}{l}-0.340 \\
(0.117)\end{array}$ \\
\hline $\begin{array}{l}\text { Medium educ* } \\
\text { hotel, rest }\end{array}$ & $\begin{array}{l}-0.457 \\
(0.048)\end{array}$ & $\begin{array}{l}-0.235 \\
(0.052)\end{array}$ & $\begin{array}{l}-0.575 \\
(0.147)\end{array}$ & $\begin{array}{l}-0.382 \\
(0.043)\end{array}$ & $\begin{array}{l}-0.362 \\
(0.044)\end{array}$ & $\begin{array}{l}-0.628 \\
(0.142)\end{array}$ \\
\hline $\begin{array}{l}\text { Medium educ* } \\
\text { transport }\end{array}$ & $\begin{array}{l}-0.209 \\
(0.049)\end{array}$ & $\begin{array}{l}-0.284 \\
(0.064)\end{array}$ & $\begin{array}{l}-0.285 \\
(0.085)\end{array}$ & $\begin{array}{l}-0.523 \\
(0.067)\end{array}$ & $\begin{array}{l}-0.637 \\
(0.070)\end{array}$ & $\begin{array}{l}-0.781 \\
(0.169)\end{array}$ \\
\hline $\begin{array}{l}\text { Medium educ* } \\
\text { finance }\end{array}$ & $\begin{array}{l}-0.646 \\
(0.044)\end{array}$ & $\begin{array}{l}-0.359 \\
(0.055)\end{array}$ & $\begin{array}{l}-0.321 \\
(0.082)\end{array}$ & $\begin{array}{l}-0.487 \\
(0.044)\end{array}$ & $\begin{array}{l}-0.514 \\
(0.048)\end{array}$ & $\begin{array}{l}-0.444 \\
(0.099)\end{array}$ \\
\hline $\begin{array}{l}\text { Medium educ* } \\
\text { education }\end{array}$ & $\begin{array}{l}-0.579 \\
(0.205)\end{array}$ & $\begin{array}{l}-0.246 \\
(0.178)\end{array}$ & $\begin{array}{l}-0.528 \\
(0.437)\end{array}$ & $\begin{array}{l}-0.453 \\
(0.138)\end{array}$ & $\begin{array}{l}-0.150 \\
(0.139)\end{array}$ & $\begin{array}{l}-0.543 \\
(0.429)\end{array}$ \\
\hline $\begin{array}{l}\text { Medium educ* } \\
\text { health service }\end{array}$ & $\begin{array}{l}-0.075 \\
(0.086)\end{array}$ & $\begin{array}{l}-0.321 \\
(0.100)\end{array}$ & $\begin{array}{c}0.213 \\
(0.152)\end{array}$ & $\begin{array}{l}0.027 \\
(0.077)\end{array}$ & $\begin{array}{l}-0.308 \\
(0.088)\end{array}$ & $\begin{array}{l}-0.234 \\
(0.189)\end{array}$ \\
\hline $\begin{array}{l}\text { Medium educ* } \\
\text { other industry }\end{array}$ & $\begin{array}{l}-0.494 \\
(0.072)\end{array}$ & $\begin{array}{l}-0.565 \\
(0.091)\end{array}$ & $\begin{array}{l}-0.567 \\
(0.189)\end{array}$ & $\begin{array}{l}-0.081 \\
(0.069)\end{array}$ & $\begin{array}{l}-0.381 \\
(0.069)\end{array}$ & $\begin{array}{l}-0.520 \\
(0.186)\end{array}$ \\
\hline Bachelor degree & $\begin{array}{l}-0.926 \\
(0.036)\end{array}$ & $\begin{array}{l}-0.721 \\
(0.052)\end{array}$ & $\begin{array}{l}-0.711 \\
(0.065)\end{array}$ & $\begin{array}{l}-0.581 \\
(0.043)\end{array}$ & $\begin{array}{l}-0.677 \\
(0.047)\end{array}$ & $\begin{array}{l}-0.590 \\
(0.091)\end{array}$ \\
\hline Graduate school & $\begin{array}{l}-1.215 \\
(0.056)\end{array}$ & $\begin{array}{l}-1.070 \\
(0.073)\end{array}$ & $\begin{array}{l}-1.120 \\
(0.108)\end{array}$ & $\begin{array}{l}-0.614 \\
(0.067)\end{array}$ & $\begin{array}{l}-1.055 \\
(0.079)\end{array}$ & $\begin{array}{l}-0.916 \\
(0.193)\end{array}$ \\
\hline $\begin{array}{l}\text { Education } \\
\text { missing }\end{array}$ & $\begin{array}{c}0.146 \\
(0.052)\end{array}$ & $\begin{array}{c}0.119 \\
(0.061)\end{array}$ & $\begin{array}{c}0.228 \\
(0.114)\end{array}$ & $\begin{array}{c}0.059 \\
(0.082)\end{array}$ & $\begin{array}{l}-0.142 \\
(0.079)\end{array}$ & $\begin{array}{c}0.014 \\
(0.150)\end{array}$ \\
\hline Experience 1-5 & $\begin{array}{l}-0.454 \\
(0.058)\end{array}$ & $\begin{array}{c}0.650 \\
(0.201)\end{array}$ & $\begin{array}{l}-0.202 \\
(0.111)\end{array}$ & $\begin{array}{c}0.223 \\
(0.059)\end{array}$ & $\begin{array}{c}0.478 \\
(0.070)\end{array}$ & $\begin{array}{c}0.133 \\
(0.129)\end{array}$ \\
\hline Exper 6-10 & $\begin{array}{l}-0.180 \\
(0.048)\end{array}$ & $\begin{array}{c}0.528 \\
(0.160)\end{array}$ & $\begin{array}{l}-0.256 \\
(0.093)\end{array}$ & $\begin{array}{c}0.388 \\
(0.046)\end{array}$ & $\begin{array}{c}0.400 \\
(0.052)\end{array}$ & $\begin{array}{c}0.036 \\
(0.091)\end{array}$ \\
\hline Exper 11-15 & $\begin{array}{l}-0.043 \\
(0.040)\end{array}$ & $\begin{array}{c}0.428 \\
(0.114)\end{array}$ & $\begin{array}{l}-0.219 \\
(0.084)\end{array}$ & $\begin{array}{c}0.334 \\
(0.035)\end{array}$ & $\begin{array}{c}0.304 \\
(0.039)\end{array}$ & $\begin{array}{c}0.145 \\
(0.060)\end{array}$ \\
\hline Exper 16-20 & $\begin{array}{c}0.011 \\
(0.031)\end{array}$ & $\begin{array}{c}0.256 \\
(0.069)\end{array}$ & $\begin{array}{l}-0.157 \\
(0.066)\end{array}$ & $\begin{array}{c}0.220 \\
(0.027)\end{array}$ & $\begin{array}{c}0.138 \\
(0.030)\end{array}$ & $\begin{array}{c}0.056 \\
(0.044)\end{array}$ \\
\hline Exper 21-25 & $\begin{array}{c}0.024 \\
(0.024)\end{array}$ & $\begin{array}{c}0.108 \\
(0.038)\end{array}$ & $\begin{array}{l}-0.043 \\
(0.051)\end{array}$ & $\begin{array}{c}0.170 \\
(0.026)\end{array}$ & $\begin{array}{c}0.072 \\
(0.029)\end{array}$ & $\begin{array}{c}0.053 \\
(0.040)\end{array}$ \\
\hline Exper $>25$ (ref) & & & & & & \\
\hline $\begin{array}{l}\text { Log earnings } \\
\text { base yr }\end{array}$ & $\begin{array}{l}-0.387 \\
(0.022)\end{array}$ & $\begin{array}{l}-0.639 \\
(0.023)\end{array}$ & $\begin{array}{l}-0.676 \\
(0.040)\end{array}$ & $\begin{array}{l}-0.009 \\
(0.027)\end{array}$ & $\begin{array}{l}-0.582 \\
(0.029)\end{array}$ & $\begin{array}{l}-0.359 \\
(0.054)\end{array}$ \\
\hline $\begin{array}{l}\text { Diff log earnings } \\
\text { from prior yr }\end{array}$ & $\begin{array}{c}0.041 \\
(0.015)\end{array}$ & $\begin{array}{c}0.140 \\
(0.015)\end{array}$ & $\begin{array}{c}0.159 \\
(0.034)\end{array}$ & $\begin{array}{l}-0.014 \\
(0.019)\end{array}$ & $\begin{array}{c}0.040 \\
(0.019)\end{array}$ & $\begin{array}{c}0.079 \\
(0.052)\end{array}$ \\
\hline $\begin{array}{l}\text { Immigrant* } \\
\text { OECD }\end{array}$ & $\begin{array}{c}0.077 \\
(0.036)\end{array}$ & $\begin{array}{l}-0.123 \\
(0.065)\end{array}$ & $\begin{array}{l}-0.030 \\
(0.064)\end{array}$ & $\begin{array}{l}-0.059 \\
(0.046)\end{array}$ & $\begin{array}{c}0.057 \\
(0.051)\end{array}$ & $\begin{array}{l}-0.133 \\
(0.100)\end{array}$ \\
\hline $\begin{array}{l}\text { Immigrant* } \\
\text { East Europe }\end{array}$ & $\begin{array}{c}0.565 \\
(0.055)\end{array}$ & $\begin{array}{c}0.196 \\
(0.092)\end{array}$ & $\begin{array}{c}0.463 \\
(0.109)\end{array}$ & $\begin{array}{c}0.263 \\
(0.074)\end{array}$ & $\begin{array}{l}-0.016 \\
(0.083)\end{array}$ & $\begin{array}{c}0.475 \\
(0.148)\end{array}$ \\
\hline $\begin{array}{l}\text { Immigrant* } \\
\text { M.East/N.Africa }\end{array}$ & $\begin{array}{c}0.891 \\
(0.062)\end{array}$ & $\begin{array}{c}0.755 \\
(0.083)\end{array}$ & $\begin{array}{l}1.444 \\
(0.125)\end{array}$ & $\begin{array}{c}0.751 \\
(0.132)\end{array}$ & $\begin{array}{l}0.587 \\
(0.134)\end{array}$ & $\begin{array}{c}0.873 \\
(0.338)\end{array}$ \\
\hline Immigrant* & $\begin{array}{l}0.319 \\
0109)\end{array}$ & 0.488 & $\begin{array}{c}0.039 \\
0260)\end{array}$ & 0.509 & 0.233 & $\begin{array}{r}0.059 \\
(0.474)\end{array}$ \\
\hline $\begin{array}{l}\text { Immigrant* } \\
\text { SE Asia }\end{array}$ & $\begin{array}{l}-0.165 \\
(0.075)\end{array}$ & $\begin{array}{c}0.136 \\
(0.088)\end{array}$ & $\begin{array}{c}0.344 \\
(0.152)\end{array}$ & $\begin{array}{c}-0.067 \\
(0.071)\end{array}$ & $\begin{array}{c}0.003 \\
(0.075)\end{array}$ & $\begin{array}{c}0.216 \\
(0.151)\end{array}$ \\
\hline Immigrant* & 0.658 & 0.500 & 0.815 & 0.722 & 0.460 & $\begin{array}{c}0.526 \\
(0278)\end{array}$ \\
\hline $\begin{array}{l}\text { Other Asia } \\
\text { Immigrant* }\end{array}$ & $\begin{array}{c}(0.065) \\
0.347\end{array}$ & $\begin{array}{c}(0.083) \\
0.134\end{array}$ & $\begin{array}{l}(0.111) \\
-0.034\end{array}$ & $\begin{array}{c}(0.107) \\
0.437\end{array}$ & $\begin{array}{c}(0.110) \\
0.402\end{array}$ & $\begin{array}{c}(0.278) \\
0.059\end{array}$ \\
\hline South America & $(0.087)$ & $(0.121)$ & $(0.214)$ & $(0.132)$ & $(0.137)$ & $(0.330)$ \\
\hline
\end{tabular}

County:

Oslo (ref) 


\begin{tabular}{|c|c|c|c|c|c|c|}
\hline Østfold & $\begin{array}{c}0.336 \\
(0.029)\end{array}$ & $\begin{array}{c}0.077 \\
(0.034)\end{array}$ & $\begin{array}{c}0.255 \\
(0.056)\end{array}$ & $\begin{array}{c}0.269 \\
(0.040)\end{array}$ & $\begin{array}{c}0.071 \\
(0.040)\end{array}$ & $\begin{array}{c}0.272 \\
(0.079)\end{array}$ \\
\hline Akershus & $\begin{array}{c}0.069 \\
(0.025)\end{array}$ & $\begin{array}{l}-0.075 \\
(0.028)\end{array}$ & $\begin{array}{c}-0.101 \\
(0.051)\end{array}$ & $\begin{array}{c}0.067 \\
(0.029)\end{array}$ & $\begin{array}{c}-0.026 \\
(0.032)\end{array}$ & $\begin{array}{c}0.087 \\
(0.064)\end{array}$ \\
\hline Hedmark & $\begin{array}{c}0.271 \\
(0.037)\end{array}$ & $\begin{array}{c}0.095 \\
(0.041)\end{array}$ & $\begin{array}{c}0.217 \\
(0.066)\end{array}$ & $\begin{array}{c}0.277 \\
(0.051)\end{array}$ & $\begin{array}{c}0.087 \\
(0.054)\end{array}$ & $\begin{array}{c}0.412 \\
(0.101)\end{array}$ \\
\hline Oppland & $\begin{array}{c}0.248 \\
(0.042)\end{array}$ & $\begin{array}{c}0.022 \\
(0.045)\end{array}$ & $\begin{array}{c}-0.075 \\
(0.081)\end{array}$ & $\begin{array}{c}0.350 \\
(0.044)\end{array}$ & $\begin{array}{c}0.147 \\
(0.053)\end{array}$ & $\begin{array}{c}0.120 \\
(0.094)\end{array}$ \\
\hline Buskerud & $\begin{array}{c}0.217 \\
(0.029)\end{array}$ & $\begin{array}{c}0.021 \\
(0.033)\end{array}$ & $\begin{array}{c}-0.149 \\
(0.058)\end{array}$ & $\begin{array}{c}0.172 \\
(0.035)\end{array}$ & $\begin{array}{c}0.030 \\
(0.041)\end{array}$ & $\begin{array}{c}-0.026 \\
(0.076)\end{array}$ \\
\hline Vestfold & $\begin{array}{c}0.144 \\
(0.034)\end{array}$ & $\begin{array}{c}0.074 \\
(0.039)\end{array}$ & $\begin{array}{c}0.216 \\
(0.061)\end{array}$ & $\begin{array}{c}0.141 \\
(0.043)\end{array}$ & $\begin{array}{c}0.110 \\
(0.046)\end{array}$ & $\begin{array}{c}0.430 \\
(0.084)\end{array}$ \\
\hline Telemark & $\begin{array}{c}0.287 \\
(0.046)\end{array}$ & $\begin{array}{c}0.117 \\
(0.045)\end{array}$ & $\begin{array}{c}0.239 \\
(0.075)\end{array}$ & $\begin{array}{c}0.252 \\
(0.051)\end{array}$ & $\begin{array}{c}0.106 \\
(0.053)\end{array}$ & $\begin{array}{c}0.514 \\
(0.090)\end{array}$ \\
\hline Aust-Agder & $\begin{array}{c}0.223 \\
(0.049)\end{array}$ & $\begin{array}{c}0.109 \\
(0.051)\end{array}$ & $\begin{array}{c}0.094 \\
(0.079)\end{array}$ & $\begin{array}{c}0.171 \\
(0.063)\end{array}$ & $\begin{array}{c}0.026 \\
(0.076)\end{array}$ & $\begin{array}{c}0.407 \\
(0.129)\end{array}$ \\
\hline Vest-Agder & $\begin{array}{c}0.310 \\
(0.042)\end{array}$ & $\begin{array}{c}0.195 \\
(0.043)\end{array}$ & $\begin{array}{c}0.355 \\
(0.071)\end{array}$ & $\begin{array}{c}0.191 \\
(0.054)\end{array}$ & $\begin{array}{c}0.146 \\
(0.058)\end{array}$ & $\begin{array}{c}0.527 \\
(0.103)\end{array}$ \\
\hline Rogaland & $\begin{array}{c}-0.175 \\
(0.034)\end{array}$ & $\begin{array}{c}-0.052 \\
(0.038)\end{array}$ & $\begin{array}{c}0.036 \\
(0.059)\end{array}$ & $\begin{array}{c}-0.231 \\
(0.042)\end{array}$ & $\begin{array}{c}0.017 \\
(0.042)\end{array}$ & $\begin{array}{c}0.115 \\
(0.078)\end{array}$ \\
\hline Hordaland & $\begin{array}{c}-0.032 \\
(0.032)\end{array}$ & $\begin{array}{l}-0.027 \\
(0.037)\end{array}$ & $\begin{array}{c}-0.248 \\
(0.057)\end{array}$ & $\begin{array}{c}-0.015 \\
(0.036)\end{array}$ & $\begin{array}{c}0.052 \\
(0.041)\end{array}$ & $\begin{array}{c}0.061 \\
(0.074)\end{array}$ \\
\hline Sogn og Fjordane & $\begin{array}{c}0.042 \\
(0.046)\end{array}$ & $\begin{array}{c}-0.039 \\
(0.050)\end{array}$ & $\begin{array}{c}-0.112 \\
(0.084)\end{array}$ & $\begin{array}{c}0.010 \\
(0.064)\end{array}$ & $\begin{array}{c}-0.035 \\
(0.065)\end{array}$ & $\begin{array}{c}-0.023 \\
(0.133)\end{array}$ \\
\hline Møre og Romsdal & $\begin{array}{c}0.018 \\
(0.038)\end{array}$ & $\begin{array}{c}-0.070 \\
(0.043)\end{array}$ & $\begin{array}{c}-0.218 \\
(0.067)\end{array}$ & $\begin{array}{c}0.095 \\
(0.047)\end{array}$ & $\begin{array}{c}0.042 \\
(0.050)\end{array}$ & $\begin{array}{c}0.090 \\
(0.092)\end{array}$ \\
\hline Sør-Trøndelag & $\begin{array}{c}0.180 \\
(0.038)\end{array}$ & $\begin{array}{c}0.055 \\
(0.041)\end{array}$ & $\begin{array}{c}0.014 \\
(0.067)\end{array}$ & $\begin{array}{c}0.226 \\
(0.041)\end{array}$ & $\begin{array}{c}0.094 \\
(0.045)\end{array}$ & $\begin{array}{c}0.205 \\
(0.085)\end{array}$ \\
\hline Nord-Trøndelag & $\begin{array}{c}0.008 \\
(0.050)\end{array}$ & $\begin{array}{c}-0.033 \\
(0.054)\end{array}$ & $\begin{array}{c}-0.157 \\
(0.085)\end{array}$ & $\begin{array}{c}0.181 \\
(0.071)\end{array}$ & $\begin{array}{c}0.092 \\
(0.068)\end{array}$ & $\begin{array}{c}0.061 \\
(0.136)\end{array}$ \\
\hline Nordland & $\begin{array}{c}0.238 \\
(0.040)\end{array}$ & $\begin{array}{c}0.212 \\
(0.052)\end{array}$ & $\begin{array}{c}0.280 \\
(0.073)\end{array}$ & $\begin{array}{c}0.297 \\
(0.051)\end{array}$ & $\begin{array}{c}0.179 \\
(0.057)\end{array}$ & $\begin{array}{c}0.644 \\
(0.097)\end{array}$ \\
\hline Troms & $\begin{array}{c}0.334 \\
(0.039)\end{array}$ & $\begin{array}{c}0.353 \\
(0.055)\end{array}$ & $\begin{array}{c}0.333 \\
(0.073)\end{array}$ & $\begin{array}{c}0.218 \\
(0.051)\end{array}$ & $\begin{array}{c}0.256 \\
(0.059)\end{array}$ & $\begin{array}{c}0.598 \\
(0.102)\end{array}$ \\
\hline Finnmark & $\begin{array}{c}0.095 \\
(0.066)\end{array}$ & $\begin{array}{c}0.442 \\
(0.133)\end{array}$ & $\begin{array}{c}0.127 \\
(0.149)\end{array}$ & $\begin{array}{c}0.007 \\
(0.087)\end{array}$ & $\begin{array}{c}0.225 \\
(0.099)\end{array}$ & $\begin{array}{c}0.140 \\
(0.181)\end{array}$ \\
\hline $\begin{array}{l}\text { Muni pop } \\
<2000\end{array}$ & $\begin{array}{l}-0.160 \\
(0.039)\end{array}$ & $\begin{array}{l}-0.038 \\
(0.047)\end{array}$ & $\begin{array}{l}-0.122 \\
(0.078)\end{array}$ & $\begin{array}{l}-0.162 \\
(0.070)\end{array}$ & $\begin{array}{c}0.063 \\
(0.067)\end{array}$ & $\begin{array}{l}-0.165 \\
(0.139)\end{array}$ \\
\hline $\begin{array}{l}\text { Muni pop } \\
2-5000\end{array}$ & $\begin{array}{l}-0.057 \\
(0.024)\end{array}$ & $\begin{array}{l}-0.042 \\
(0.028)\end{array}$ & $\begin{array}{l}-0.053 \\
(0.045)\end{array}$ & $\begin{array}{l}-0.061 \\
(0.035)\end{array}$ & $\begin{array}{l}-0.025 \\
(0.037)\end{array}$ & $\begin{array}{c}0.080 \\
(0.070)\end{array}$ \\
\hline $\begin{array}{l}\text { Muni pop } \\
5-10,000\end{array}$ & $\begin{array}{l}-0.037 \\
(0.021)\end{array}$ & $\begin{array}{l}-0.016 \\
(0.026)\end{array}$ & $\begin{array}{l}-0.020 \\
(0.040)\end{array}$ & $\begin{array}{c}0.020 \\
(0.030)\end{array}$ & $\begin{array}{c}0.003 \\
(0.032)\end{array}$ & $\begin{array}{c}0.087 \\
(0.058)\end{array}$ \\
\hline Muni pop & $\begin{array}{c}0.020 \\
(0.017)\end{array}$ & $\begin{array}{c}0.014 \\
(0.019)\end{array}$ & $\begin{array}{c}0.091 \\
(0.032)\end{array}$ & $\begin{array}{c}0.004 \\
(0.023)\end{array}$ & $\begin{array}{c}0.011 \\
(0.025)\end{array}$ & $\begin{array}{c}0.094 \\
(0.046)\end{array}$ \\
\hline Muni $>50,000$ (ref) & & & & & & \\
\hline $\begin{array}{l}\text { Firm size base yr } \\
11-25\end{array}$ & $\begin{array}{l}-0.039 \\
(0.026)\end{array}$ & $\begin{array}{l}-0.094 \\
(0.036)\end{array}$ & $\begin{array}{l}-0.010 \\
(0.040)\end{array}$ & $\begin{array}{l}-0.223 \\
(0.030)\end{array}$ & $\begin{array}{l}-0.093 \\
(0.036)\end{array}$ & $\begin{array}{l}-0.203 \\
(0.056)\end{array}$ \\
\hline $\begin{array}{l}\text { Firm size } \\
26-50\end{array}$ & $\begin{array}{l}-0.058 \\
(0.027)\end{array}$ & $\begin{array}{l}-0.120 \\
(0.037)\end{array}$ & $\begin{array}{l}-0.013 \\
(0.041)\end{array}$ & $\begin{array}{l}-0.203 \\
(0.031)\end{array}$ & $\begin{array}{l}-0.121 \\
(0.037)\end{array}$ & $\begin{array}{l}-0.102 \\
(0.057)\end{array}$ \\
\hline $\begin{array}{c}\text { Firm size } \\
51-200\end{array}$ & $\begin{array}{l}-0.042 \\
(0.027)\end{array}$ & $\begin{array}{l}-0.087 \\
(0.039)\end{array}$ & $\begin{array}{l}-0.007 \\
(0.039)\end{array}$ & $\begin{array}{l}-0.098 \\
(0.030)\end{array}$ & $\begin{array}{l}-0.073 \\
(0.036)\end{array}$ & $\begin{array}{l}-0.054 \\
(0.053)\end{array}$ \\
\hline $\begin{array}{l}\text { Firm size } \\
>200 \text { (ref) }\end{array}$ & & & & & & \\
\hline No turnover & $\begin{array}{l}-0.167 \\
(0.022)\end{array}$ & $\begin{array}{l}-0.195 \\
(0.028)\end{array}$ & $\begin{array}{l}-0.028 \\
(0.041)\end{array}$ & $\begin{array}{l}-0.169 \\
(0.032)\end{array}$ & $\begin{array}{l}-0.176 \\
(0.033)\end{array}$ & $\begin{array}{l}-0.026 \\
(0.060)\end{array}$ \\
\hline
\end{tabular}




\begin{tabular}{|c|c|c|c|c|c|c|}
\hline Turnover $0.1-10 \%$ & $\begin{array}{l}-0.149 \\
(0.017)\end{array}$ & $\begin{array}{l}-0.183 \\
(0.022)\end{array}$ & $\begin{array}{l}-0.009 \\
(0.030)\end{array}$ & $\begin{array}{l}-0.145 \\
(0.020)\end{array}$ & $\begin{array}{l}-0.167 \\
(0.023)\end{array}$ & $\begin{array}{l}-0.004 \\
(0.040)\end{array}$ \\
\hline Turnover 10-15\% & $\begin{array}{l}-0.105 \\
(0.018)\end{array}$ & $\begin{array}{l}-0.164 \\
(0.026)\end{array}$ & $\begin{array}{l}-0.012 \\
(0.034)\end{array}$ & $\begin{array}{l}-0.112 \\
(0.022)\end{array}$ & $\begin{array}{l}-0.115 \\
(0.025)\end{array}$ & $\begin{array}{c}0.005 \\
(0.044)\end{array}$ \\
\hline Turnover 15-20\% & $\begin{array}{l}-0.057 \\
(0.020)\end{array}$ & $\begin{array}{l}-0.117 \\
(0.022)\end{array}$ & $\begin{array}{c}0.003 \\
(0.035)\end{array}$ & $\begin{array}{l}-0.039 \\
(0.023)\end{array}$ & $\begin{array}{l}-0.070 \\
(0.026)\end{array}$ & $\begin{array}{c}0.030 \\
(0.046)\end{array}$ \\
\hline \multicolumn{7}{|l|}{$\begin{array}{l}\text { Turnover } \\
>20 \% \text { (ref) }\end{array}$} \\
\hline $\begin{array}{l}\text { Early retirement } \\
\text { eligible }\end{array}$ & $\begin{array}{l}-0.410 \\
(0.036)\end{array}$ & $\begin{array}{c}0.643 \\
(0.042)\end{array}$ & $\begin{array}{l}-0.637 \\
(0.042)\end{array}$ & $\begin{array}{l}-0.246 \\
(0.057)\end{array}$ & $\begin{array}{c}0.619 \\
(0.057)\end{array}$ & $\begin{array}{l}-0.542 \\
(0.068)\end{array}$ \\
\hline \multicolumn{7}{|l|}{$\begin{array}{l}\text { No downsizing } \\
\text { (<10\%) (ref) }\end{array}$} \\
\hline $\begin{array}{c}\text { Downsize } \\
10-20 \%\end{array}$ & $\begin{array}{c}0.049 \\
(0.022)\end{array}$ & $\begin{array}{c}0.181 \\
(0.040)\end{array}$ & $\begin{array}{c}0.142 \\
(0.033)\end{array}$ & $\begin{array}{c}0.078 \\
(0.025)\end{array}$ & $\begin{array}{c}0.122 \\
(0.028)\end{array}$ & $\begin{array}{c}0.055 \\
(0.049)\end{array}$ \\
\hline $\begin{array}{c}\text { Downsize } \\
20-35 \%\end{array}$ & $\begin{array}{c}0.102 \\
(0.019)\end{array}$ & $\begin{array}{c}0.198 \\
(0.025)\end{array}$ & $\begin{array}{c}0.171 \\
(0.034)\end{array}$ & $\begin{array}{c}0.072 \\
(0.024)\end{array}$ & $\begin{array}{c}0.162 \\
(0.027)\end{array}$ & $\begin{array}{c}0.118 \\
(0.049)\end{array}$ \\
\hline $\begin{array}{l}\text { Downsize } \\
\text { 35-99.9\% }\end{array}$ & $\begin{array}{c}0.163 \\
(0.019)\end{array}$ & $\begin{array}{c}0.342 \\
(0.029)\end{array}$ & $\begin{array}{c}0.320 \\
(0.033)\end{array}$ & $\begin{array}{c}0.049 \\
(0.021)\end{array}$ & $\begin{array}{c}0.301 \\
(0.024)\end{array}$ & $\begin{array}{c}0.204 \\
(0.042)\end{array}$ \\
\hline $\begin{array}{c}\text { Closure with } \\
\text { bankruptcy }\end{array}$ & $\begin{array}{c}0.412 \\
(0.041)\end{array}$ & $\begin{array}{c}0.712 \\
(0.040)\end{array}$ & $\begin{array}{c}0.631 \\
(0.061)\end{array}$ & $\begin{array}{c}0.280 \\
(0.047)\end{array}$ & $\begin{array}{c}0.658 \\
(0.051)\end{array}$ & $\begin{array}{c}0.341 \\
(0.097)\end{array}$ \\
\hline Liquidation & $\begin{array}{c}0.075 \\
(0.028)\end{array}$ & $\begin{array}{c}0.348 \\
(0.033)\end{array}$ & $\begin{array}{c}0.241 \\
(0.049)\end{array}$ & $\begin{array}{c}0.107 \\
(0.032)\end{array}$ & $\begin{array}{c}0.338 \\
(0.037)\end{array}$ & $\begin{array}{c}0.226 \\
(0.062)\end{array}$ \\
\hline Takeover & $\begin{array}{c}0.003 \\
(0.020)\end{array}$ & $\begin{array}{c}0.046 \\
(0.032)\end{array}$ & $\begin{array}{c}0.023 \\
(0.033)\end{array}$ & $\begin{array}{c}0.094 \\
(0.023)\end{array}$ & $\begin{array}{c}0.073 \\
(0.026)\end{array}$ & $\begin{array}{c}0.076 \\
(0.044)\end{array}$ \\
\hline $\begin{array}{l}\text { Firm identifier } \\
\text { mismatch I }\end{array}$ & $\begin{array}{c}0.031 \\
(0.053)\end{array}$ & $\begin{array}{c}0.195 \\
(0.056)\end{array}$ & $\begin{array}{c}0.171 \\
(0.090)\end{array}$ & $\begin{array}{c}0.018 \\
(0.068)\end{array}$ & $\begin{array}{c}0.180 \\
(0.065)\end{array}$ & $\begin{array}{c}0.114 \\
(0.129)\end{array}$ \\
\hline $\begin{array}{l}\text { Firm identifier } \\
\text { mismatch II }\end{array}$ & $\begin{array}{l}-0.030 \\
(0.053)\end{array}$ & $\begin{array}{l}-0.092 \\
(0.057)\end{array}$ & $\begin{array}{c}-0.040 \\
(0.118)\end{array}$ & $\begin{array}{c}0.105 \\
(0.069)\end{array}$ & $\begin{array}{c}0.065 \\
(0.066)\end{array}$ & $\begin{array}{c}0.010 \\
(0.121)\end{array}$ \\
\hline $\begin{array}{l}\text { Return on } \\
\text { capital }\end{array}$ & $\begin{array}{l}-0.014 \\
(0.008)\end{array}$ & $\begin{array}{l}-0.078 \\
(0.024)\end{array}$ & $\begin{array}{l}-0.041 \\
(0.013)\end{array}$ & $\begin{array}{l}-0.043 \\
(0.009)\end{array}$ & $\begin{array}{l}-0.039 \\
(0.012)\end{array}$ & $\begin{array}{l}-0.042 \\
(0.018)\end{array}$ \\
\hline $\begin{array}{l}\text { Change in return } \\
\text { on capital }\end{array}$ & $\begin{array}{l}-0.022 \\
(0.008)\end{array}$ & $\begin{array}{l}-0.052 \\
(0.019)\end{array}$ & $\begin{array}{l}-0.026 \\
(0.013)\end{array}$ & $\begin{array}{l}-0.021 \\
(0.009)\end{array}$ & $\begin{array}{l}-0.031 \\
(0.011)\end{array}$ & $\begin{array}{l}-0.030 \\
(0.019)\end{array}$ \\
\hline $\begin{array}{l}\text { Risk of unempl } \\
\text { index }\end{array}$ & $\begin{array}{c}0.163 \\
(0.029)\end{array}$ & $\begin{array}{c}0.000 \\
(0.036)\end{array}$ & $\begin{array}{c}0.177 \\
(0.049)\end{array}$ & $\begin{array}{c}0.117 \\
(0.031)\end{array}$ & $\begin{array}{l}-0.018 \\
(0.033)\end{array}$ & $\begin{array}{c}0.085 \\
(0.061)\end{array}$ \\
\hline $\begin{array}{l}\text { Prob of reempl } \\
\text { index }\end{array}$ & $\begin{array}{l}-0.076 \\
(0.024)\end{array}$ & $\begin{array}{l}-0.195 \\
(0.026)\end{array}$ & $\begin{array}{c}0.024 \\
(0.036)\end{array}$ & $\begin{array}{l}-0.030 \\
(0.031)\end{array}$ & $\begin{array}{l}-0.181 \\
(0.032)\end{array}$ & $\begin{array}{l}-0.080 \\
(0.050)\end{array}$ \\
\hline Period 2 & $\begin{array}{c}0.368 \\
(0.019)\end{array}$ & $\begin{array}{c}0.311 \\
(0.036)\end{array}$ & $\begin{array}{c}0.064 \\
(0.034)\end{array}$ & $\begin{array}{c}0.409 \\
(0.024)\end{array}$ & $\begin{array}{c}0.316 \\
(0.026)\end{array}$ & $\begin{array}{c}0.049 \\
(0.040)\end{array}$ \\
\hline Period 3 & $\begin{array}{c}0.411 \\
(0.023)\end{array}$ & $\begin{array}{c}0.323 \\
(0.033)\end{array}$ & $\begin{array}{l}-0.168 \\
(0.034)\end{array}$ & $\begin{array}{c}0.521 \\
(0.024)\end{array}$ & $\begin{array}{c}0.416 \\
(0.025)\end{array}$ & $\begin{array}{l}-0.158 \\
(0.045)\end{array}$ \\
\hline Constant & $\begin{array}{l}-2.199 \\
(0.052)\end{array}$ & $\begin{array}{l}-2.599 \\
(0.064)\end{array}$ & $\begin{array}{l}-4.131 \\
(0.113)\end{array}$ & $\begin{array}{l}-2.126 \\
(0.065)\end{array}$ & $\begin{array}{l}-2.385 \\
(0.073)\end{array}$ & $\begin{array}{l}-3.844 \\
(0.143)\end{array}$ \\
\hline
\end{tabular}

Note: Listed parameters are coefficients from the logit regressions underlying results presented in Tables 5 and 6. Standard errors are reported in parentheses and are clustered within firm-by-period cells. Regressions in columns 1-3 have 524,270 observations (34,620 cluster units), and regressions in columns 4-6 have 174,194 observations (29,700 cluster units). Continuous variables are entered as deviation from their sample mean. "Experience" measures cumulative years with labor earnings or self-employment income exceeding the base amount of the national insurance system (72,000 NOK in 2009, approximately 11,500 USD). Turnover in the base year is defined as max(number of new hires, number of quits) during the year divided by the number of employees at the start of the year. "Firm identifier mismatch I" and "mismatch II" denote firm identifiers that disappear from the employer-employee data but not from the accounting data and vice versa. 